\title{
Glimpses of the scenography of Farnesian shows in Spain: Carlo Passetti's Filo
}

\section{Esther Merino}

Department of Art History, Faculty of Geography and History, UCM

Complutense University of Madrid

emerino@ucm.es

Abstract: Parma, the capital of the lands ruled by the Farnese family, was one of the most active centres in Italy in the design of architectures for shows. A proposal for an approach to the history of Italian scenography during the Seicento is presented here - a some what in depth view is presented as it is not very well known in Spain - using iconological and semiotic analyses of the decorations for the staging of the libretti, beginning with the scenographic creations of Giovan Battista Aleotti, and finishing with Carlo Pasetti, one of his most fruitful heirs, focusing on his work with the opera La Filo overo Giunonerepacificata con Ercole, created by Francesco Berni (1631), a preserved copy of which can be found in the Library of the El Escorial Monastery (Madrid), a rare fact amongst the works with Florentine origin collected in Spanish document repositories, even though it became, with other scenographies of the same author, a powerful inspiration for several courtesan parties (theatre shows, choreographed dance or carousels) in Spain during the XVII and XVIII centuries.

Keywords: Theatre architecture, History of scenery, Courtly semiotics, Giovan Battista Aleotti, Carlo Passetti, La Filo.

\section{History. Theatre ARChitecture in the Emilia Region}

\section{The role of the scenographer}

The scenographer in Italy emerges during the first thirty years of the XVII century as a versatile artist, with wide knowledges in different sciences, as well as engineer, architect, scholar, machine inventor and even constructor of the new theatre buildings that go beyond the faithful copy of the greco -latin model with wider functions, that required more complex transversal supervision. A professional figure with an enormous amount of social prestige such as in the cases of Giulio Parigi (1571-1635) in the Florence of the Medici and in the environment of Padania, Gian Battista Aleotti (1546-1636), known as "Argenta1", who worked for Alfonso II as his court architect, military engineer, supervisor of the water network and remarkable expert in mechanics, translating eventhe illustrated and commented works of Hieron of Alexandria. He had designed for the Gonzaga family of Mantua the setsfor the performance of the famous Pastor Fido, Gian Battista Guarini's pastoral play, in 1598, even though he can be found settled in Ferrara at the beginning of the next century, in a close intellectual and creative collaboration with one of the most brilliant men of his time, which was Enzo Bentovoglio, the perfect courtier described by Castiglione, with whom he achieved the specific training to obtain the maximum propagandistic effect of the sets of the new show ceremonial.

Shortly after 1600 he founded,with other remarkable scholars from Ferrara, like GuidobaldoBonarelli, the Academy of the Bold, which is one of the first examples of cultural promotion institutions under the aegis of their aristocratic sponsors, as a source of legitimacy of their power. These institutions can be traced back to the

1. To enhance the role of Aleotti in relation with predecessors and peers, like Parigi, Torelli, Chenda or Guitti, it is necessary to recall the fact that Aleotti designed built La Pilotta theatre because it sets the pattern of theatrical architecture during the XVII and XVIII centuries for the playful celebrations of the european courts. However, there are not many works available about this fascinating individual. Amongst them can be found (Fiocca, 1998) and (Mattei, 2010)

www.arjonline.org 


\section{Glimpses of the scenography of Farnesian shows in Spain: Carlo Passetti's Filo}

late medieval rhetoric chambers, with a long tradition of classical studies, seeking to achieve an archaeological restitution of literary, emblematic and symbolic resources,these resources were gradually channelled through the shows as a means of indoctrinating, as in many other Italian works. Thus, the baroque libretto emerged as a new literary typology ${ }^{2}$, where all kinds of tips can be found, apart from the dialogues of the plot, including descriptions and engravings about the scenography and news about the vocal virtues and vital events of the main characters of the setup.In 1605 the Academy decided to find a new stable site as headquarters of its activities, including the scenography set for dramatic shows. For such purpose they found an old barn near the church of saint Lorenzo, that was refurbished by Aleottialso, in what is considered one of the first projects of baroque theatre architecture. Aleotti's theatre at Ferrara, the reference for Parma, incorporates innovative elements as compared with previous designs ${ }^{3}$, such as the proscenium triumphal arch, that frames the stage as an albertian window - but separatingit from the arena or orchestra, now renamed as square - apart from the harrow, everything integrated in what is considered the prototypical design of the architecture of the baroque show. It was initially restored by Francesco Guitti, disciple of Aleotti in 1626. In 1660 this first theatre for Aleotti'sIntrepidi ${ }^{4}$ became the Obizzi Theatre, remodelled by Carlo Pasetti (1639-1695), featuring an irregular plant, up to june 1679 , when it was destroyed by fire.

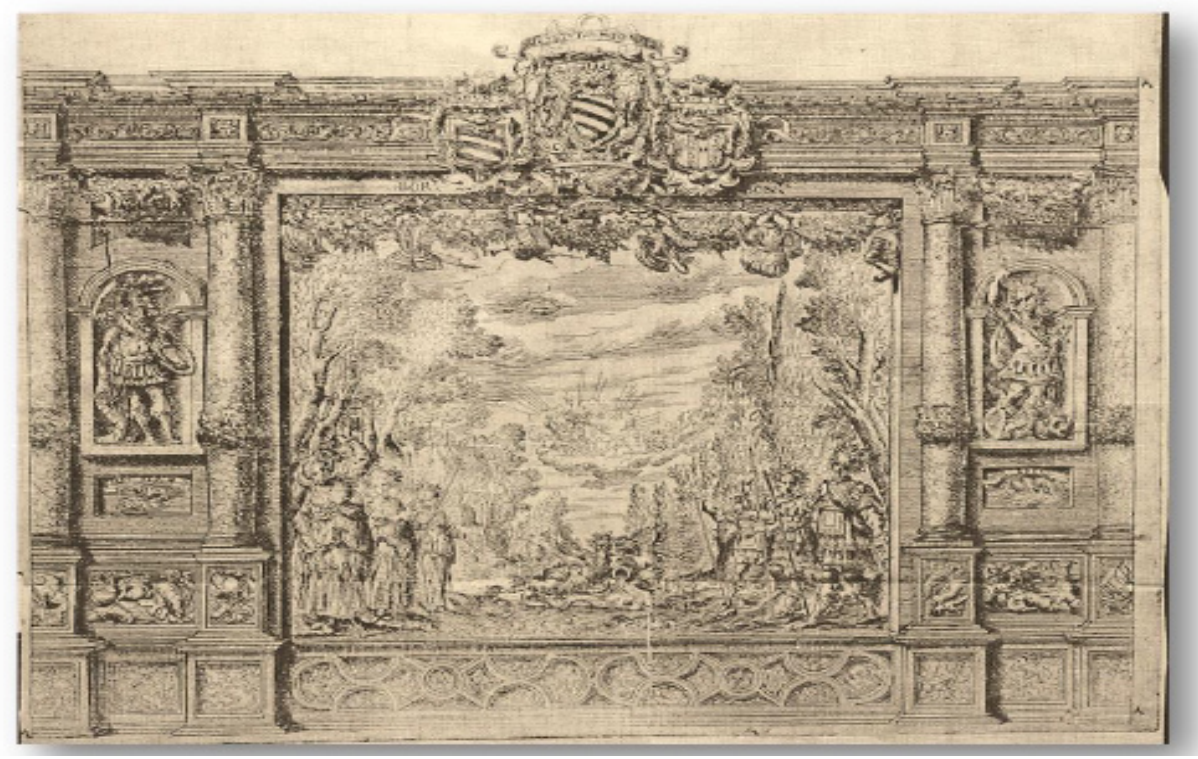

Fig1. Alfonso Rivarola "Il Chenda". Teatro provisional, decoraciones y maquinaria para la representación del Torneo titulado L'Alcina Maga Favola Pescatoria, con ocasión del Carnaval de 1631, en la Sala de los Gigantes del Castello-Palazzo de Ferrara.

This structure, willing to endureand integrated in the masonry, is the result of a continuous experimentation and invention exercise that Aleotti had already assimilated with the practice of the TeatroOlimpico ${ }^{5}$ of Vicenza,

2. One of the first catalogues collecting the libretto genre is (Pietropaolo, 2011), even though the encyclopaedic works of (Sartori, 1990-1994) had previously been written

3. (Pirrotta, 1984)

4. In F. Berni's text L'Alcina, FavolaPescatoria, Ferrara 1631 it says that the temporary theatre created by Alfonso Rivarola "Il Chenda" was built in the Giants Room of the Castello-Palazzo, probably referring to the so called Giochi Room in the first floor, linking it with the decorations by SebastianoFilippi, known as Bastianino (Ferrara 1532-1602), with mythological frescoes with the subject of the giants with an archaeological scenographic background pointing to the roman wall painting of the same subject. "A questo fine la Sala, che bien detta de Giganti (come quella, ch ènellostesso piano del TalamodestinatoallefelicissimeNozze)... Diròsolo, che quelluogorappresentava al vivo le Pompe, e le bellezze del Teatro, che nellanostracittàalzaronoquegl'Intrepidi, i cui NomisarannosemprevivinelleBocchedella Fama..., p.3

5. In relation with the shape of the prototypical theatre architecture represented by the Gran Teatro of Parma and the influence of its predecessors, some news about older works must be cited such as those from Irving, as well as some newer and settled already as classical, such as those from Puppi, Schrade, Gallo, Carandini or Mazzoni, because they connect with the other buildings that are accepted as classical, 
and tested in the Theatre of the Bold; projecting it now in the building of the Parma Ducal Palace, moving the frons scenae to the forefront of the proscenium in what was his main contribution; from thereon he will manage freely in an architectonic style that will spread not just through the north of Italy, but becoming a prototypic model throughout Europe

\section{The Farnese Theatre from Parma}

The Farnese Theatre from Parma was admired and visited during its construction until its effective opening in 1628 , becoming a reference of stable or temporary theatre architecture, influencing directly the works of some of the followers of Aleotti such as Francesco Guitti (1605-1645) and Alfonso Rivarola (1590-1640), known as "Il Chenda". Both participated actively in the opening ceremony in 1628. Guitti was also the author of another example of this type of architecture devoted to the hosting of various festive shows, like the Great Theatre, made of wood, that was temporarily erected in the Cortileof Saint Pietro Martir. The close links between Ferrara and Parma were always there. A similar structure to the one of the set of the Tournament named La Contesa, that took place in 1638 in the Palazzo Bevilacqua in Ferrara, where a seven-sided polygonal stand surrounded an oval plant and several stages of arcaded galleries communicated between each other by stairs with a ruined architrave.

In 1617 duke Ranuccio I Farnese knew that Cosme II of Medici had the intention to go on a pilgrimage to Milan, thus he decided to anticipate himself sending an invitation to the Great Duke of Tuscany, promising that he would be honoured in the farnesian states following the old roman triumphant receptions, because he knew that the Florentine very much liked festive entertainments, to which he was used at the Uffizzi Theatre, following the designs of Bernardo Buontalenti (1531-1608). It was then when the idea of building a theatre within the Ducal Palace was conceived with a lavish looking and representing the political and dynastic advantages of the Farnese family, envisioning a possible marriage of the son of Ranuccio with a Medici woman.

The Palace of La Pilotta had recently been built by Ranuccio I's father the great general Alejandro Farnese (1596-1622), who had the emperor Charles V as ancestor. From the spatial point of view the enormous palace had several yards or cortiles and many service rooms with the purpose of hosting all kinds of noble entertainments, like tournaments and ball games, from where the building took its name. Moreover, the new urban design included a big structuring square as ceremonial centre, whose backstage was the palatine building, to endow greater elegance to the capital of the preabsolutist principality, following the same pattern as in the Pitti Palace, becoming the permanent scenography of what will become the landscaped theatreof Boboli ${ }^{6}$ in Florence, created by Giulio and Alfonso Parigi, a kind of prototype named "palace-square" as the control structure of the celebration. Following this thoughtit was decided to fit a rectangular room in the palace, initially devoted to weapons room in the first floor, that was was remodelled so as to host festive celebrations permanently.
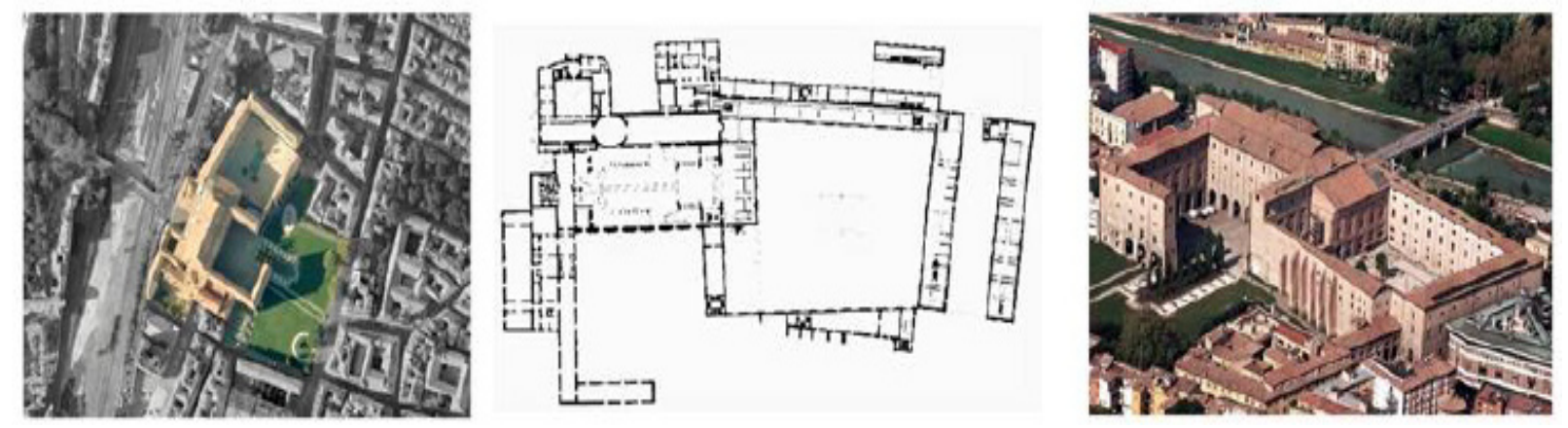

Fig2. Construido alrededor de 1580, durante los últimos años del Ducado de Ottavio Farnese, la intención era construir un edificio rectangular en forma de galería unido al Palazzo Ducal. Este palacio, presenta tres patios: el Cortile di S. Pietro Martire (hoy, conocido como el Cortile della Pilotta), el Cortile del Guazzatoio y el Cortile della Racchetta.

beginning by (Puppi, 1963) and (Schrade, 1960)

6. Opened in 1637 with the show Le nozzedeglidei

American Research Journal of History and Culture

Page 3 


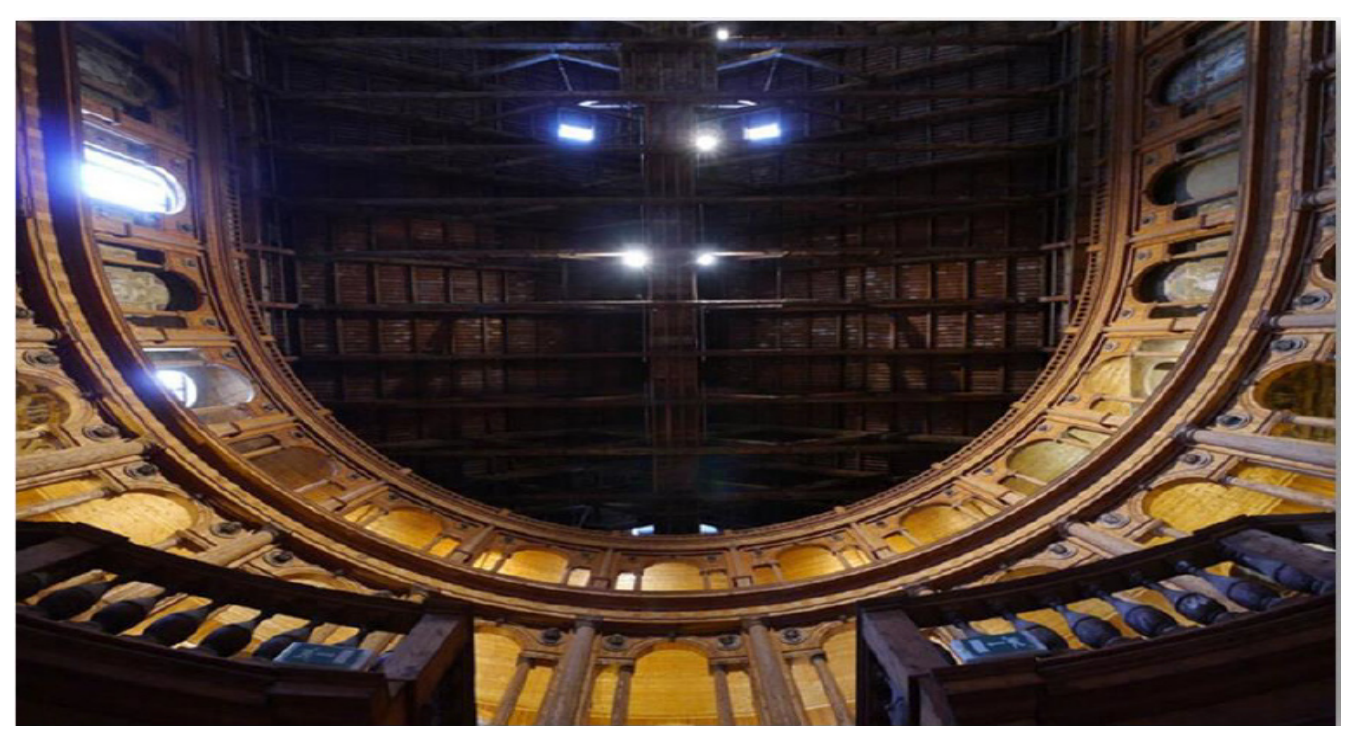

Fig3. Interior del Teatro Farnese

The venture of the theatre became the jewel of the principality besides many other interesting wonders for the duke, as his art works collection; prodigies such as the grotto with automaton and the menagerie, all of which derives from the surprise and the rarities of the mannerist thought. Assessment was demanded to the experts of the Academy of the Bold and to Enzo Bentivoglio, one of its founders and well known throughout Italy as producer of the public shows generating a great political impact, for the renewal of the space devoted to the theatre. Moreover, Aleotti was at the time being in Parma with his task force, assistants, painters and the rest of the qualified workers that began the complete refurbishment of the room a few months before.

Due to an unveiled reason, a few months later, in march 1618, the architect abandoned the worksite, having already been decided the design of the new structure, the main solutions for the reconditioning of the space and even the scenographic machinery for the opening day show. May be he came back to supervise the rest of the tasks that had continued after his sudden departure, even though the works management had been undertaken by the piacentian scholar Alfonso Pozzo (1580-1626), hosted as a page in the parmesan court, thereafter following ecclesiastical studies in Rome and performing some diplomatic activities for Ranuccio in Genoa and Venice, among others, apart from being named bishop of Borgo de San Donnino.Count Pozzo was asked previously to design the allegoric program for the decoration of the theatre, as well as the texts for the Intermezzi of the opera-tournament that was going to take place the same opening day, whose title was $L a$ Difesadella Bellezza, so that during this period he had to multiply himself to fulfil all these tasks.

Everything became frustrated with all this deployment of resources and thoughts when at the beginning of 1619 news arrived about the cancellation of the trip of the duke of Tuscany due to health reasons. All the arrangements had no sense, including the works of theatre upgrading and the scenography of the planned event. Ten years after, both Ranuccio and Cosme had passed by and it was their offsprings, Odoardo and Margarita at their marriage the ones to open the magnificent space designed by Aleotti.

Once it has been assumed how spectacular the building must be as an essential element of baroque thought, it becomes the paradigmatic example of the absolutist show, where the mixture of subjects from the greco-latin mythological culture strained at maximum both metaphorically and by analogy, with the deep metabolization of the values of the world of chivalry following the arthurian medieval tradition.

The entire building is made with wood and polychrome plaster that simulates marble's textures. The upper part of the tiers is topped by a double arcaded gallery with an overlapping Serlian, displaying frescoes in the 


\section{Glimpses of the scenography of Farnesian shows in Spain: Carlo Passetti's Filo}

peripheral walls and crowned by a balustrade. Even though the boxes were not defined, the organization of the space implied the assumption of the hierarchical-social criterium, that included the allocation of the ducal family in the closest area to the stage, so that the preference vision of the show could be achieved, thus contributing to "doing life happier"7 The great "piazza" bounded by the caveais now used for hosting, among others, the equestrian choreographies of the new formats of the show, the thematic tournaments ${ }^{8}$, the armed encounters becoming strictly ruled, becoming named "Carrusel"- one of which was planned for the opening day -. This space was also created with the purpose of becoming the place to reproduce the old spectacular formula of the Naumachia, that had been essayed with remarkable success by Buontalenti in the Cortile of the Pitti Palace in Florence.

The dimensions had multiplied themselves in relation with previous examples, in order to host the stage machinery that was introduced with the purpose of increasing the look, both spectacular and surprising of the sets, in the background of the stage andabove and below the floor, where the intricacies are "hidden" and the mechanism allows the movement and articulation of the theatre set, to whom Aleotti refers in a letter addressed to Ranuccio in march 1618, that might have been tested previously in the Theatre of the Bold in Ferrara, among other reasons.

\section{"furo posti in opera alcuni di queitellari, che dovrannofare le scene che dovranandareinanti e indietro".}

At both sides of the proscenium arch and separating this space from the stands, like in Sabbioneta ${ }^{10}$, there are two triumphal arches in a fresco trompe l'oeil, simulating a loggia, as if it were an extension of the same arched gallery of the cavea, that behaves as the scene background of a couple of three dimensional equestrian figures representing Alejandro and Octavio Farnese made in plaster. This illusionistic decoration included a celestial vision in the ceiling, a mythological sky with representations of the zodiac and of the olympic gods, that was created by a studio of "quadraturistic" painters from the Emilian region, GirolamoCurti, known as "ilDentone" and LionelloSpada, was destroyed during the bombings of 1944, of which there are almost no descriptions, only some photographs and engravings.

\section{Scenography}

During all the XVII century the creative environment was very fruitful for the scenographers in Parma. Apart from Aleottti, Chenda or Guitti, connected, as has been shown, to the decorations during the first decades of the Farnese Theatre of Parma, afterwards the scenography and the machines conceived by CristoforoRangoni, called "Picarelli", especially those for the Il Ratto di Elena ${ }^{11}$, the drama written by Bernardo Morando, one of the most 7. (Cirillo, 1989)

8. The ancient structure of the Theatre changes according to the new uses and habits in the show, so that the old classicalorchestra becomes the frame for possible aquatic shows like The Andromeda (1638), surrounded by a wall that protected the musicians, located in the first strands, not having originated in Parma, seeming a previous solution adopted in 1621 by the pioneer scenographer Giulio Parigi for the production of El Martirio de Santa Ágata at the Oratory of the Fraternity of Saint Anthony in Florence, were the musicians were placed behind a similar wall, in front of the stage, displacing the stairs to both sides

9. (Carandini, 1995), citing (Ciancarelle, 1987).The Communal Library of Ferrara hosts the priceless document collection, known as Antonelli Collection, about the scenography decoration and machinery, consisting of forty four letters of an enormous relevance and delicious reading, among which several from Francesco Guitti, disciple of Aleotti, others from the Count Fabio Scotti, butler of the Duke of Parma, and some others from Antonio Goretti, amateur musician and friend of Monteverdi, in charge of the musical arrangements for the building, as well as some from the Count Alfonso Pozzo, member, at the time being of the court of Ranuccio I himself. The exhaustive study of (Lavin, 1964) can be consulted

10. The theatre designed by Palladio in Vicenza was a paradigmatic and groundbreaking building having been thoroughly studied by (Mazzoni, 2013) who includes some biographical and professional news about Vincenzo Scamozzi (1548-1616), as well as the complete story about the creation of the building in the heart of this ideal city that was Sabbioneta about the symbolic interpretation of the decoration, and no forgetting the outstanding figure of its sponsor Vespasiano Gonzaga (1531-1591). A broad analysis of the structure of the architectonic space appears in one of these, with a great precision in the naming, as the evolution of the "display room", apart from including an enormous compilation of references about the history of the Italian show. See Manzzoni in one of the chapters of (Ojeda, 2013)

11. With music of SimplicianoUlivi 


\section{Glimpses of the scenography of Farnesian shows in Spain: Carlo Passetti's Filo}

prolific scholars, linked to current cultural centres and amongst them the Academy of the Incogniti in Venice, that was described as "unascenamoltogrande e attrezzata...un miracolodell'Arte...cherassembradisordinato, $e$ confuso, regola con ordineproporzionato le machine, e dàlegge a glistupendi los moti"12.

Bolognese and Cremonese painters actively participated in the manufacturing of decorative tapestries for the scene of the Farnese Theatre, as can be assessed from the letters of the Antonelli Collection ${ }^{13}$ and some clues are provided about the simulated vision with which the scenography was developed within which appeared the machines that represented the different roles, most of them of the pagan cosmology, like "La Machina di Marte", "tutte le Machine del Salone", as is described in the documents:

“...le prospetive, maglihofattovedere che la scenasaràpiena da quatro Cori per le quatroparti del Mondo, e la sortita di Plutone con glipersonaggiinfernali...", “L'Auroral'abbiamofattasorgereancopiùlontanaassaidal mezzo dellaprospetiva”, "fingendo di essere su la Nave degl'Argonauti”, “...di trasmutare gliquatroCavaglieri di Plutone", "La prima Comparsa seràil Palazzo d'Armida", "...ravvivate la Tragica , e la Infernale", "sorgere la Città di Dite...farla venir presso la Boscarecia, con certeanimellefattealla traversa de telari..., “...che facciail buco d'una Caverna...."

Even though the graphic designs of these descriptions are not kept, it is impossible not to recognize them in the prints of other scenographers not less representative of the Seiscento, like Giulio Parigi and Ludovico OttavioBurnacini ${ }^{14}$, that might be useful to grasp an idea of the impacting effect of the sets in the Farnese Theatre

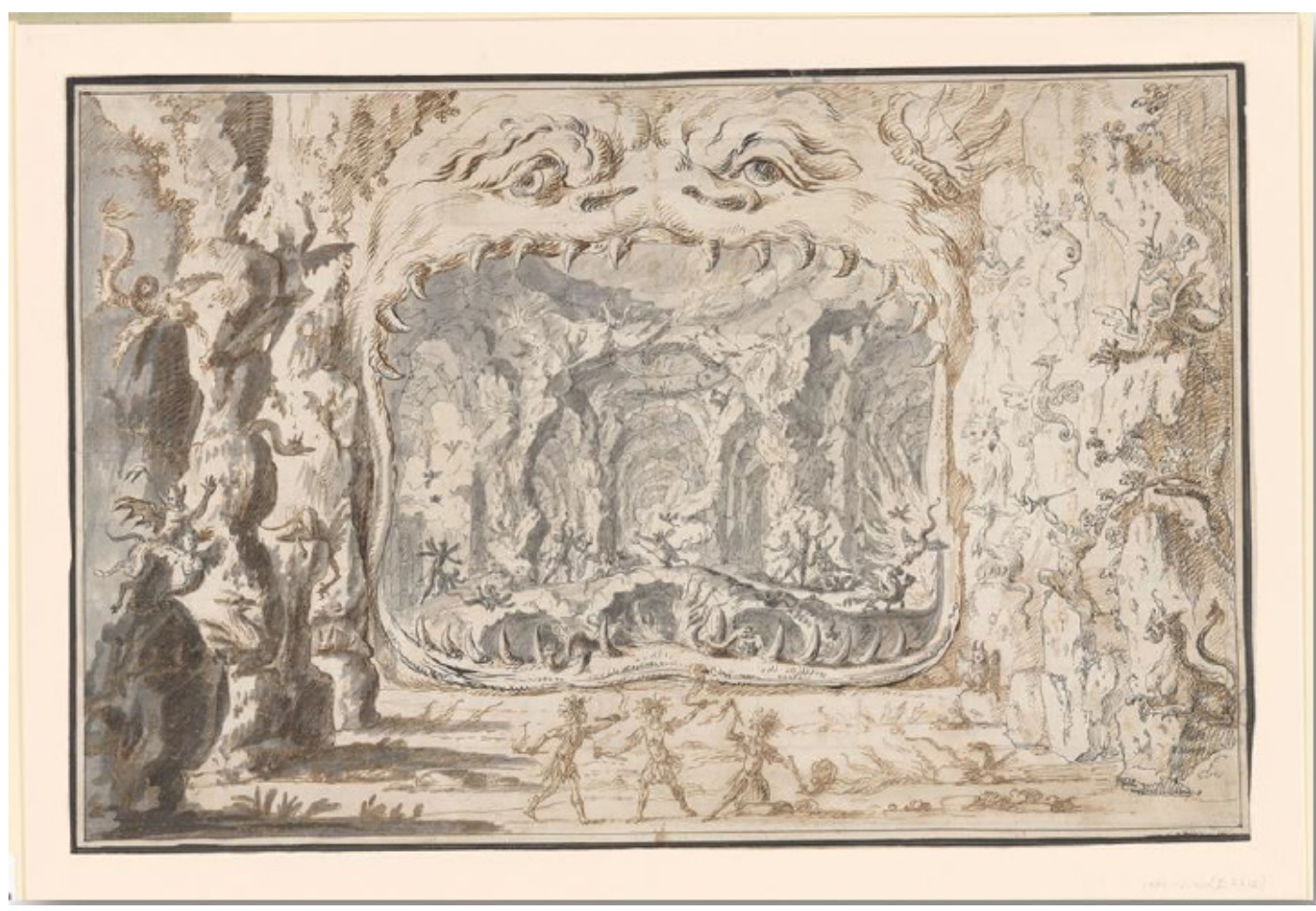

Fig5. Giulio Parigi, A Hell Mouth in the Lower World.ca. 1620. The Morgan Library \& Museum. Procedente de la colección del escenógrafo Americano Daniel Oeuslager (1902-1975). Y anteriormente Wilhelm Alexander Freund, Berlin (Lugt 1894). http://www.themorgan.org/drawings/item/187284

12. (Carandini, 1995)

13. Antonelli Collection, collected by (Lavin, 1964) 14. (Merino, 2008) 


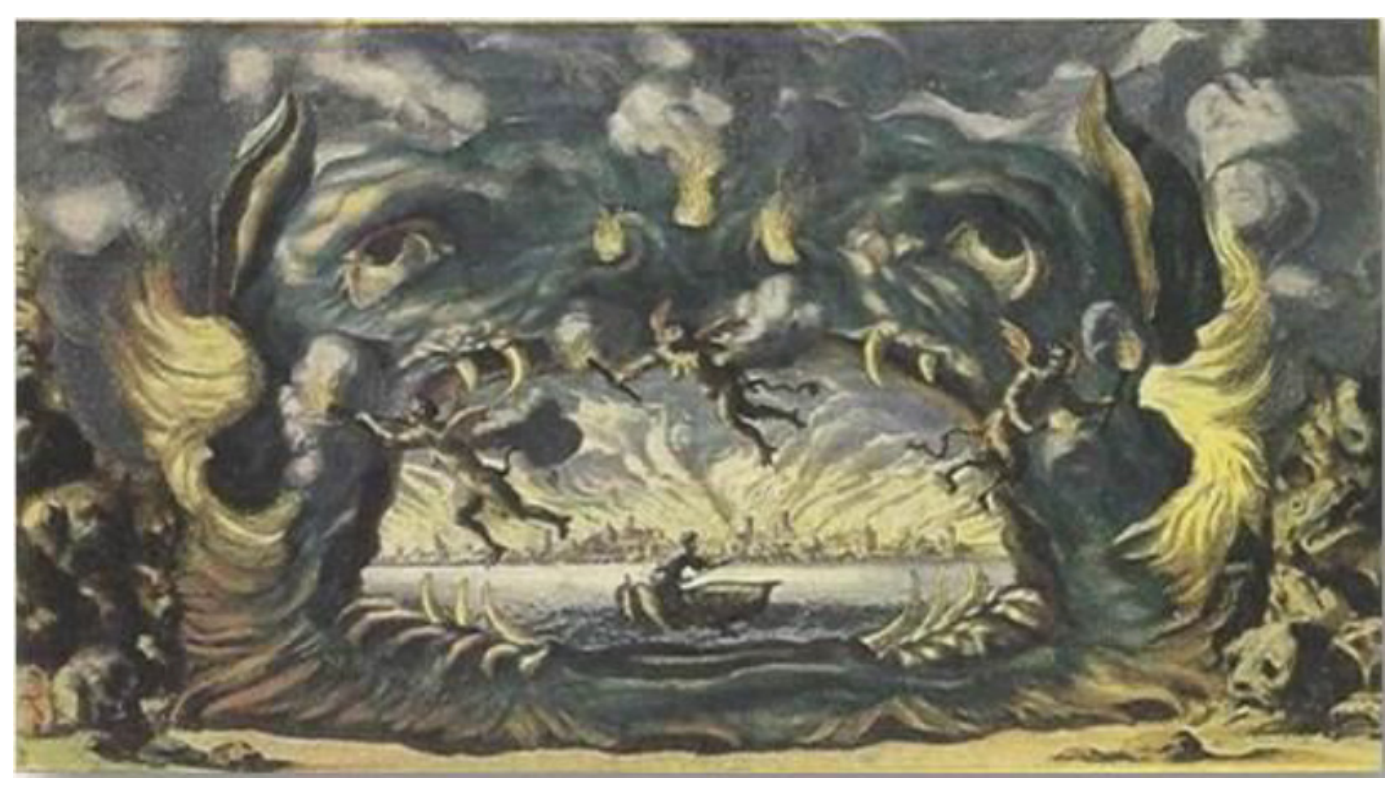

Fig6. Ludovico Burnacini Para el montaje de I1pomo d' Oro (1668)

\section{Music}

During all de Middle Ages until the end of the XV century, there are hardly any testimonies of historic sources about the musical civic institutions. It is known that the $13^{\text {th }}$ of march of 962 , the first centre in Parma devoted to music had originated from a licence of emperor Oton I in favour of Uberto , bishop of Parma, so that musical education could be included as a discipline in the General Studies of Liberal Arts: "The four mathematical sciences were thus arithmetic, music, geometry and astronomy...on what refers to music voices and singing and sounds with instruments such as the organ are taught and with instruments in harmony with each other for the delight of the people, or in the church, for Our Lord's service". In such a way it is stated in the Los Libros del Tesoro of BrunettoLatini ${ }^{15}$, the contemporary Florentine that Dante sent to Hell.

Gradually several musical instruments began to appear graphically. The Franciscan fray Salimbene from Adam or from Parma (1221-1290) does not mention the relevance of music in the social context in his Cronica (1288).It was considered an unnecessary resource, even though it was assumed that it was part of the popular "displays of joy". Salimbene tells that in 1233 that peace was celebrated with songs of big choirs of voices, sounds and instruments. He mentions Benedetto, a frail, named "Cornetta" due to the instrument he used to play. Musicians and dancers were not very well received in the city and fray Salimbene complained in his story about the insensitivity that the parmesans showed in their service to God with the scarce promotion of comedians, minstrels and actors. Only when the Farnesian duchy was born, popular music institutions did exist.

Palatine music in the theatres became more usual since the creation of the Farnese court, from 1545, which is the moment when there is documental evidence of the service of musicians being demanded. In fact, with the arrival of Pier Luigi to the duchy, he hurried to create the Court Chapel for which he might have even looked outside the territory for the virtuosi of chant and instruments, as is stated in a letter dated on the $28^{\text {th }}$ January of 1546 written by the piacentian Vincenzo Parabosco, similarlyas the Olympics of Vicenza did afterwards to compose the music for the shows they promoted, as at the opening of the show of Sofocles' Edipo Tyrant ${ }^{16}$.

15. Book I, part I, III, Come la natura di tutte le cose è divisa in quattromaniere secondo teoria

16. Designs of the sketches for the costumes, the scenography and a detailed description of this singular show, can be found in (Gallo, 1973), with a prologue from (Puppi, 1963). About the Olympic Theatre, not less needed are other works of (Mazzoni, 1998) and (Mazzoni, 2013) 
Glimpses of the scenography of Farnesian shows in Spain: Carlo Passetti's Filo

Maybe it might be another innovation in the Parma Theatre, due to the importance they attributed to music in the creation of a global and integrated show, whose design, using Monteverdi's words, could both "trovarel' Armonia"17 of a conditioned space, having found a solution to the problem of placing the musicians in a coherent way, illustrating the interdependence of music and architecture.

The Court Capellaincluded everybody that had to do with music, like singers and musicians that gradually specialised, particularly since 1603 when the group of the Company of Violins was unified. And they not only played the role of courtly chapel, but they joined the musicians in the opera shows or the singers of the cathedral and other types of shows., wherever they were needed. They included renowned musicians, like, for example, Marco Uccellini (virtuous author of sonatas and music for the theatre), Giuseppe Veturini (well known for his direction with optimum execution); even though the Capella de Corte was also directed by foreign masters like Alessandro Ghivizzani (in 1622), from Luca, or the roman Francesco Courcelle (1727-1732) from Piacenza, who undertook in 1731 the music for the memorial service of Antonio, the last duke of the Farnese dynasty.

In Parma memorable events took place, under the government of this dynasty, like in 1583, when La Danza di Venere was performed, a pastoral play written by Angelo Ingegneri, the same sponsor of the Edipo Rey, with which the Theatre of the Olympics in Vicenza opened. With the XVII century the epicentre of the show moved to the Theatre in the Ducal Palace, becoming the symbol of the greatness of its principals. It is often remembered the activity of Benedetto Ferrari in this environment, court musician between 1619 and 1623 and author of Pastor Regio, performed in Piacenza in 1646; or the great Francesco Manelli, court singer in 1642 and after capella master, comprehensive artist and managerof the ballet Ercolenell'Aridano, performed in Piacenza in 1651 based on the libretto written by Bernardo Morando, apart from other works,. It was also Morando's, now at Parma Theatre, the staging of Il rattod'Europa in 1653, using in this case the text of EluezioSandri and in 1660 the show that is going to be addressed here: La Filo overoGiunonerepacificata con Ercole, followed by the tournament I seGigli ${ }^{18}$, both based in the libretti of the scholar Francesco Berni.

It is paradoxical that after so many efforts, both intellectual and material, the Farnese Theatre of La Pilotta, for some the magnificent theatrical museum of the duke of Parma, only opened five times for courtly parties ${ }^{19}$. One of these was for the celebration of the wedding of Ranuccio II andViolante of Saboy, with the scenography designed by Carlo Pasetti (1639-1695), whose work coincides at Ferrara with the one of Alfonso Parigi and with Ferdinando Taccaat Florence ${ }^{20}$

17. Antonelli Collection, letter 7, signed by Francesco Guitti in february 1628 and 32 from Antonio Goretti cited by (Lavin, 1964)“... percheiogliaccomodato un loco per suobeneficio, chemoltogligiova: il quale è súl piano dellascalainferiore in questamaniera. Il Campo A è forato, e vàsu'l piano del Salone, e será coperto da una Ballaustra che lo circonda, e non serannovedutigl'Instrum. tianziaccompagnamirabilmente la Scena...Le Scalepossonoessere dentro e quando si vorrà, si possonospingerefuori con bella maniera, e'lsemicircolo C. será vestitod'unemuraglia che difenderà i Musicidall'acqua...una parte di muraglianeldeto loco dellascala per salvare li strumenti e Claviorgano che si guidica di doverliponere..."

18. One of most memorable events in the organization of parties during the modern period, were the Binche Parties, organized by the queen Mary of Hungary in honour of her nephew, that would after be Philip II, when his European presentation as imperial heir by his father Charles V. It was usual the link between different episodes of pastimes and here the Torneo I seiGigli is also mentioned in La Filo, when the third act has finished in the page 253it says "QuìVenere, Pallade, Flora, e l'Aurorafatterivali per l'acquisto de seiGigli, vanno a provedersi di guerrieripelcombattimento, che ne dovràseguireun'altra sera nelTorneo".

19. The last one took place in 690, for the wedding of Odoardo with Dorotea Sophia of Neoburg, with a show that was as famous as the opening one, Il Favoredegli Dei by Aurelio Aureli and the scenography of Domenico Mauro and Ferdinando GalliBibiena(Cirillo, 1989) 20. The magnificent collection of the Estense Library can be consulted at http://bibliotecaestense.beniculturali.it

American Research Journal of History and Culture

Page 8 


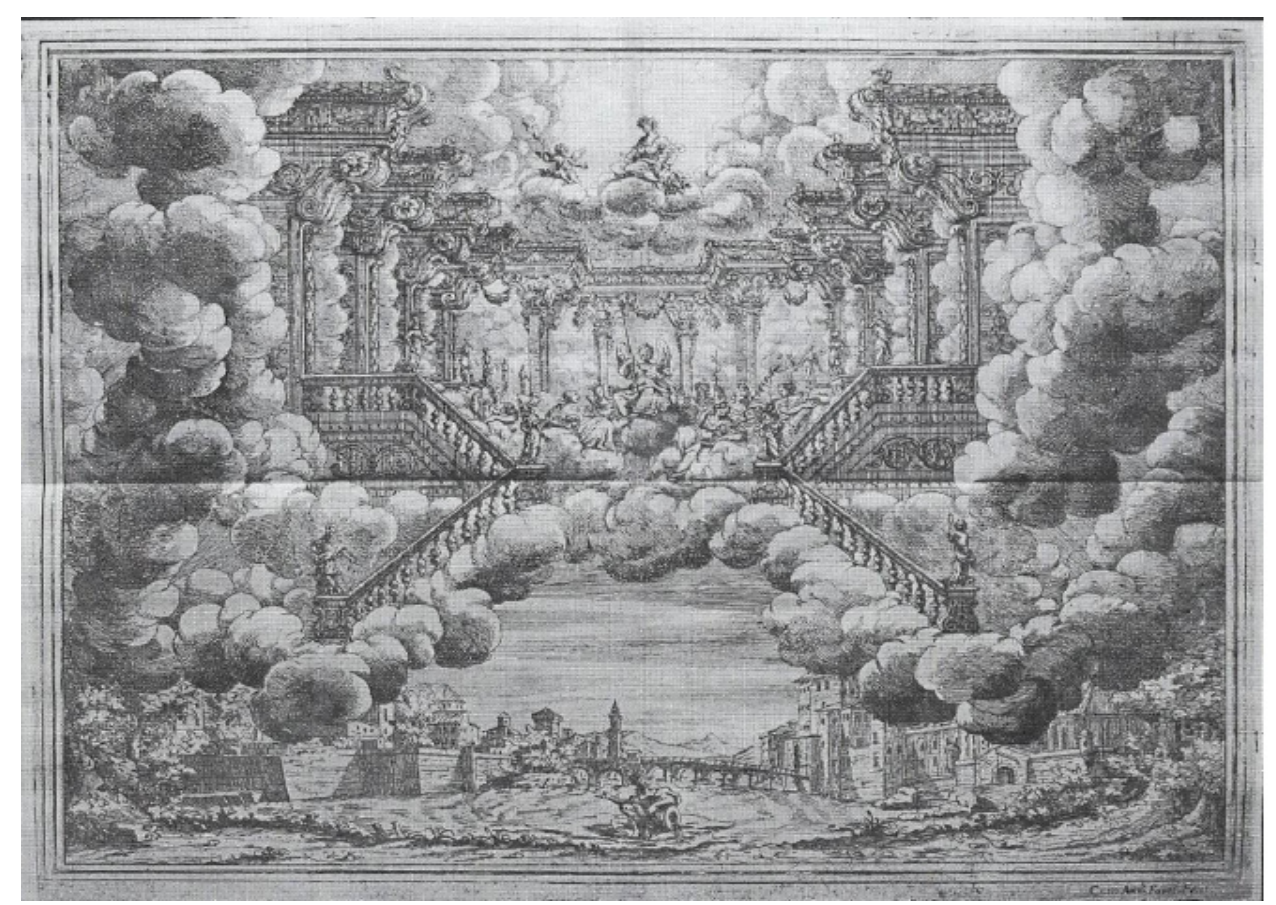

Fig4. Estampa de Carlo Antonio Forti, Francesco Galli Bibiena escenógrafo y Stefano Lolli como "maquinista teatral", Reggia delle Virtù, en L'Eta dell'Oro. Introduzione al Balletto della Serenissima Signora Principessa Margherita e delle Signore Dame, con ocasión del matrimonio con Odoardo Farnese, Poesía del Dottore Lotto Lotti y Música de Giuseppe Tosi, Piacenza, Stampa Ducale del Bazachi, 1690. Representación en el "Teatrino di Corte".

\section{Parma in the XVII century}

Ranuccio II began to rule at 18, after ten years of regency of cardinal Francesco Maria Farnese and Margarita, her mother. Once governing he had to tackle with the pressures of Cardinal Mazarino so as to maintain the duchy of Parma neutral against the strains that confronted France with Spain, seeking to insure the passage of the so called "Spanish road", that threatened the French frontiers. Afterwards this neutrality became compromised in 1643 in the conflict of the siege of the Castro fortress (whose duchy they lost finally in 1666) by the papal troops, apart handing over to the church all the parmesan possessions strategically placed within the Papal States. In 1660 took place the wedding between Ranuccio II, son of Edoardo, with Margarita Violante, daughter of the duke of Saboy and of Christine of France, sister of Louis XIII, trying to pleaseand assure the protection of the French kingdom, what, in the end was an anti-roman policy. The last years of Ranuccio's government were difficult and complex to maintain the old hegemony, due to the Austrian military occupation by imperial troops. To oppose the devastating effects, the second wedding of the duke was agreed with Dorotea-Sofia of Neoburg in 1690, that could lead to magnificent relationships with the Spanish court, where the queen, Mariana, was sister of the bride.

In what has to do with domestic policies, Ranuccio strived to maintain stability, strengthen the administrative structures and the urban organization, including a judiciary like a ministry of justice (1652), and favoured the economic development of the textile industry, located in Piacenza, as well as the private promotion of mining, agricultural production and commerce.

Culture went through a phase of modernization and special flourishing with the creation of centralized archives, the Ducal Archives that were secret, and others that helped the management of the Chambre Ducale 


\section{Glimpses of the scenography of Farnesian shows in Spain: Carlo Passetti's Filo}

and the Notarial Archives, founded under two regulations dated 1648 and 1679. All this was accompanied with a substantial increase in the cultural activity and intellectual level, with the creation, among others, of the Museum of Inscriptions, the Royal Art Gallery and the Library, that was organizedwith a cataloguing method sponsored by the duke. Without forgetting the importance for education of he University, the Nobles College and several other educational and cultural institutions like the different Academies, besides the sponsoring of several scientific endeavours and historic research, on which distinguished figures participated actively, like the historian Vittorio Siri or the benedictine Benedetto Bacchini.

Entertainment and great striking effects characterized the farnesian court in what concerns parties and shows. This achievement was feasible due to the concentration of many artists, musicians, painters, sculptors and men of letters, that took part in the different events with their oversized budgets that contributed to worsen the finance situation of the citizens burdened by so many taxes.

\section{Carlo Pasetti, scenographer of parmesan parties}

Little is known about the biography of Carlo Pasetti, creator of the scenography both of the show and the tournament, apart from his birth in Ferrara in 1613, dying in the same city the $28^{\text {th }}$ of December 1679 . He had NiccoloCabeo as master in mathematics, de Vacchi and Bassi of Verneda in military architecture, Girolamo Rossetti in hydrostatics and Francesco Guitti in scenography. Better known is his intense professional activities at the service of the Apostolic Chamber in his native city, simultaneously as military engineer he has been attributed the construction of the fortifications of Primaro, of Cento, of Vigarano and Pontelagoscuro. Gradually he specialized as "theatre engineer"21, both for the Obizzi and for the Bentivoglio, but also in Parma and Vienna occasionally in the famous staging of La Contessadell'aria et dell'aqua

The first news about his theatre works date back to 1650, when he prepared two shows in Ferrara ${ }^{22}$ with a libretto from Francesco Berni: Le Palme d'Amore ${ }^{23}$ at theObizzi Theatre and Il Ratto di Cefalo ${ }^{24}$ at the Theatre of the Big Room of the Palace for which he invented new machinery and improved the already existing, not being too innovative, apparently, in the design of the scenographic decoration. His staging, following the usual

21. The name of "theatre engineer"became widespread by the end of the XVII century. Under this name Ludovico OttavioBurnacini is referenced, with whom Pasetti worked in Austria as part of the commissions of emperor Leopoldo I, see (Poleross, 2003)

22. The repeated referenceabout the relationship between Parma and Ferrara is unavoidable because the influence of the latter on the configuration of the parmesan style, when even the different professionals moved to Parma requested for their experience and knowledge in the protocol of courtly parties. References to Pieri or Zorzi are thus appropriate, because they develop a theatre history of wide spectrum, contextualizing the piece of literature within the framework of the scenic arts and its meaning in relation with the contribution of the resource of the "albertian window". Ferrara was one of the places where the interest for the flourishing of the "show environment", or what is the same the scenographic setting of the literary recreations, where the city became the background of the different told tales. Simultaneously, the revitalization of the classical authors took place with the same forefront, using their works for the arguments of these setups, initially somewhat improvising and whose direction was undertaken initially by painters or architects coming from the multipurpose humanist universe in the absence of the professional role of the scenographer. (Zorzi, 1977). At the beginning of the Seicento, the experimentation in the implementation of the show in the ceremonial of what is known as "the playfulness of power", was especially fruitful in Ferrara despite the transfer of the capital of the court of the Este to Modena, because the theatrical culture consolidated under the patronage of the marquis Alfonso II (1533-1597) prevailed. Since the end of the XV century Ferrara had become one of the clues of political strategy, surviving on the knife's edge of the dominant power confrontation between the French and the Spanish, making use of difficult blood related alliances with the families governing in Milan, Mantua and Venice. At the same time when the Sforza, the Gonzaga o the Della Rovere tried to become strong in their lands, they strengthened the courtly environments with artistic patronage and cultural promotion, that were used as ornament of their dynastic legitimacy. Most of this promotion was the edition of the texts of Antiquity, recovered without stop once they switched back the view to the past and became convinced about their ethical, aesthetical and fruitful virtues from the point of view of the analogy with these courts as "new Romes". The many shows promoted both by Ercole II and by Alfonso II, where GiraldiCinzio replaced Ariosto as court author, helped to institutionalize the playful celebration in the politics of the city, as was already happening in other cities at the end of the XV century and first decades of the XVI century, where the intense activity of artists, with full time jobs on the setting of many stagings for the courtly playfulness, can be found,like in the case of the famous Leonardo (Pieri, 1989)

23. In the occasion of the wedding of Francesco Maria Mosti and CaterinaPia of Saboy

24. After Francesco Berni'sIl Ratto di Cefalo in 1651 he engaged the staging of Mattiopli's and F. Laurenzi's. L'esiliod'Amore. In this same place in 1653 he undertook the decorations for the stagings of Mattiol'sL'Antiopa and L'Orizia in 1665, with libretto from the same author on the event of the queen Cristine of Sweden coming into Ferrara. 


\section{Glimpses of the scenography of Farnesian shows in Spain: Carlo Passetti's Filo}

system, included chariots appearing at the top moving to the ground, called "flights", machines that represented clouds, capable of performing several diagonal movements and changes at the sight of the audience. In 1652 he went a little further, when he built a temporary theatre at the Miroglio Palace in Ferrara for the staging of Glisforzi del desiderio; even though 1660 was, without any doubt, Passetti's most important year of his career, who, as Engineer of the Great Farnese Theatre ${ }^{25}$, had to take care about the decorations and the machinery of La FiloossiaGiunonerappacificata con Ercole(with music of Francesco Manelli),created by Francesco Berni, as well as the stagings of the thematic tournaments named I seigigli (with music also by Francesco Manelli) and La garadeglielementi $i^{26}$.

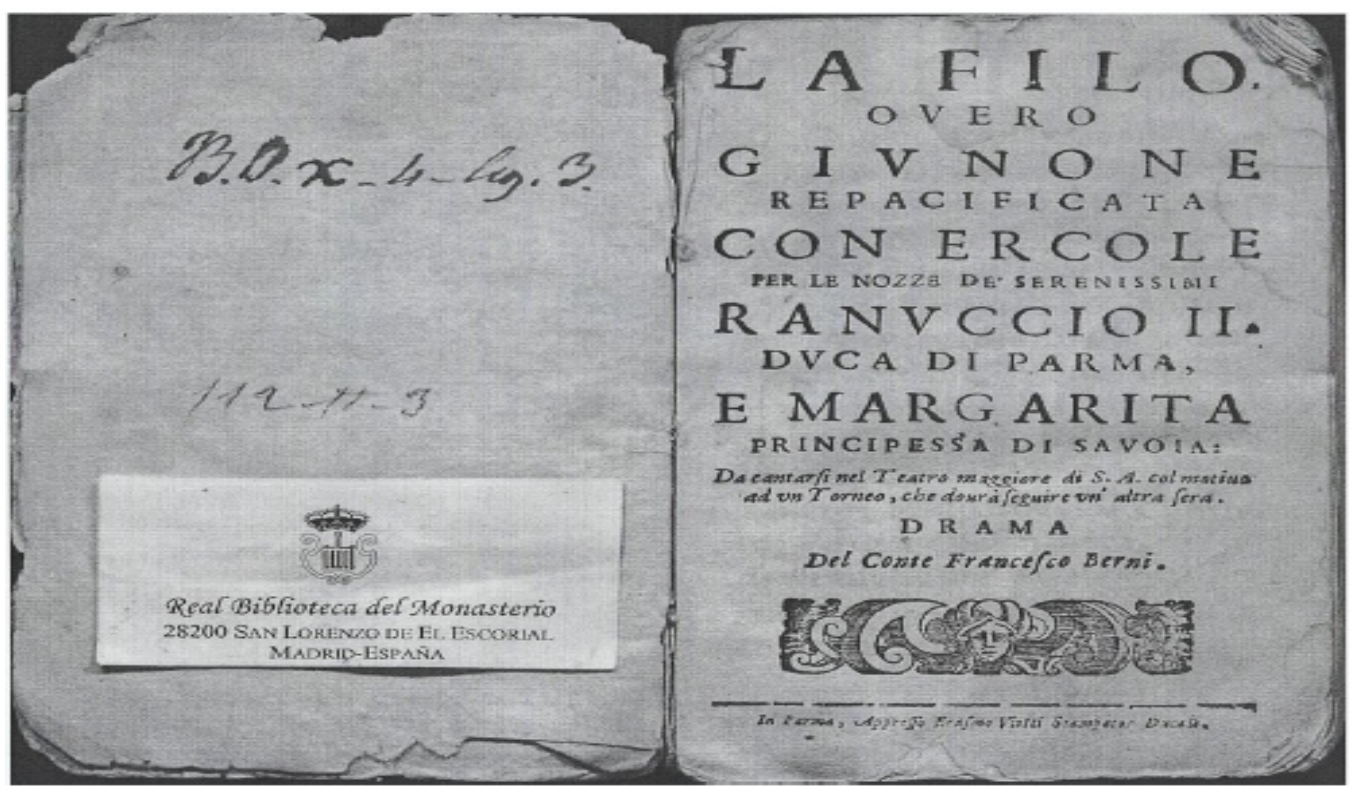

Fig7. La Filo.Frontis.

\section{The works of Carlo Pasetti}

La Filo's great show reopened, in fact, La Pilotta Theatre after eight years of silence ${ }^{27}$ on the wedding of Ranuccio II with Margarita Violante of Savoy. The play, considered a musical drama likeagreek tragedy, great complexity, intrigue and parts with substantial dialogues, but solid symbology, required many movements in order to introduce both the mythological and human stories, included within the different levels that were already common since Buontalenti's Intermezzi ${ }^{28}$, terrestrial and celestial, where the gods main characters of the conflict were assumed to live: Juno and Cupid against Jupiter and Hercules. In any case, it was well received since it can reflect the main objective of these kind of show, that was the glorification of the Farnese, equated with gods and heroes of Greco Latin Olympic mythology, it had a great success.

To begin, the prologue deepens in the subject of the passage of time, that had already been dealt with in a previous party in 1652 at the palatine Theatre, when stagingVicende del Temps, inviting thereon to epically state the virtues and deeds of the ducal family, in front of the gods, as a means of opening the show, with an scenographic background representing the city of Parma, so as to put into context the theatrical fiction, as the engravings of many of the libretti published that have to do with the show environment represent.

25. As a difference with the "Teatrino di Corte" built by Stefano Lolli at the beginning of November 1688 on the left side of the Big one 26. In this case the music was Benedetto Ferrari's and took place in the Piazza Maggiore of Parma

27. The libretto of La Filo includes a prologue and three acts with four intervals in between, the last one of which works as the epilogue, where the episode that was after developed independently in the I seiGigli tournament was presented, being shown after it and in the same place.

28. The Pioneer studies of (Warburg, 1859), that can be read on line at http://tems.umn.edu/pdf/Warburg-Theatrical.pdf 


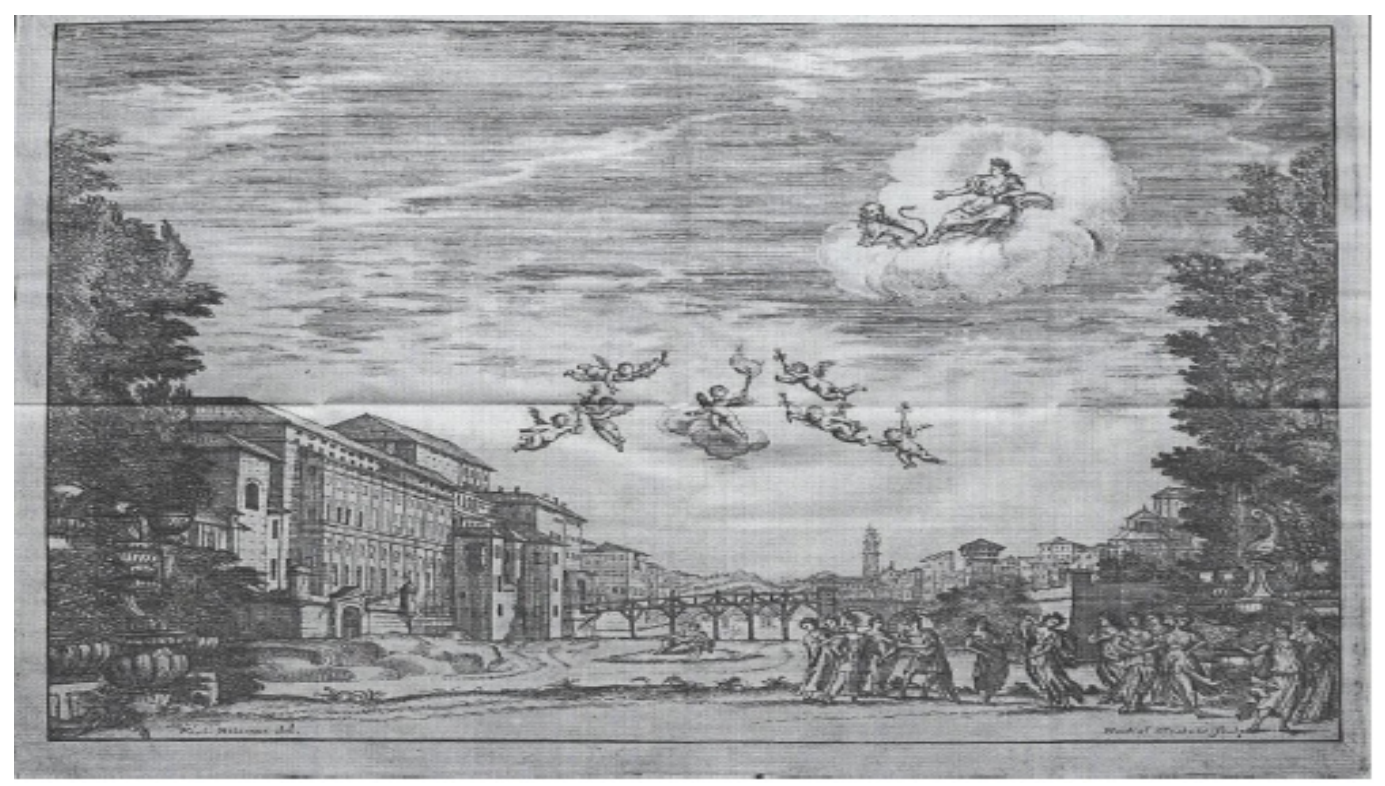

Fig8. Estampa de Martial Desbois y Ferdinando Galli Bibiena escenógrafo, Veduta di Parma dal greto del torrente o Vista de la ciudad de Parma, en L'Eta dell'Oro. 1690, que se representó en el llamado Teatrino de Corte.

The action of the first interval of La Filo introduces the bridal issue. It includes plenty of laudatory symbols of the dynasty, like, for example, the fleur de lys and the everlasting Golden Fleece, that establishes symbolically the legendary link with the imperial Habsburgs. Inspired in the conflict between Juno and Hera (as the goddess of marriage) and Jupiter that takes place in the Judgement of Paris, recovered in one of its first occasions in the staging of the Il giudizio di Paride, with decorations designed by Michelangelo Buonarroti ${ }^{29}$ in Florence in 1608. Thus, with Berni's invention the return of a golden age to the duchy was foreseen, thanks to the union of the Farnese and the Saboys and as result, prosperity and affluence owed to the wedding.

The history of the main character, Filo, daughter of Alcimedon, Arcadia's hero- points to the most learned tradition of the Italian theatre, around the myth of Hercules and Omphale ${ }^{30}$, though dealt with some freedom. That is why the action takes place in the court of Omphale, in Meonia, the original name for Lydia, like so many others that inhabited the libretti of the baroque shows, in this case taking as a reference the tales of DiodoroSiculo due to the exotic attraction of those places in the public imagination of the modern age, that allowed the artists to come off the proprieties, enriching the decorative and expressive speech of the characters that used to play the counterpoint to the hero, the pathos faced to the classic ethos.

The plot is created during the first instants, when Filo reaches the court searching for her beloved Hercules disguised as a man, covered by the name of Rosmiro. Under such conditions, the rivalry with Omphale result, and that is the substance of Berni's text, full of love misadventures, violent passions, wordplays and misunderstandings, whose dramatic emotional tension often breaks up with situations that almost limit what is mockery and bizarre, confronting tragedy with comedy; without missing the character of the witch inspired by Circe, playing here the role of the Argea wizard, thanks to whose ployan earthquake is introduced as a great scenographic upheaval that ruins the walls of the palace where Hercules was retained by Eros, that works as a cathartic end for the first act, similarly to the staging of Armida's myth.

29. (De Santis, 2012)

30. After the murder of Iphito, Hercules was punished by being sold to the queen of Lydia, Omphale, who made him her lover though maintaining him chained, as a way of representing symbolically the female domination 
Glimpses of the scenography of Farnesian shows in Spain: Carlo Passetti's Filo

Hercules meets Omphale in a forest, beginning a dance where all the court participates, becoming a satiric masquerade with comical dialogues played by the servant Falcone, prototype of the comic servant from the commedia dell'arte in the role of comic hero. The beautiful Lampa also appears and a simulated encounters take place between Hercules and the Centaurs, which is another of the traditional issues of the olympic mythology and of the classical iconography, since they were mentioned, once again in the celebration of a wedding, in the marriage of Piritoo and Deidamia, symbolic representation of the dionysian facing the apollonian rational restraint of the dramatic hero par excellence. When the third act finishes, a scene of joy concludes after plenty of hardships where Hercules solves all the conflicts (against the Giants, the Nemea lion and several ill - fated prophecies). It is the moment when he recovers Filo's love.

The complexity of the show is increased thanks to the possibility of expanding its spectacularity with the use of apparatus and scenic machinery, especially during the intervals, and here is where Pasetti could use all his experience, including devices for creating surprising effects, the appearance of ghosts, of corpses, animated sculptures and choirs of singing angels, that reflect a substantial tuning with the so called "machinist school"scenography of the second half of the XVII century, that focuses on increasing the surprising effects for the audience and of the scenic movement, but without forgetting the text of the libretto.

In this case, the libretto of La Filo does not contain engravings of scenes that might graphically illustrate the scenographic decoration designed and used by Pasetti, even though there are plenty of tips. On the other hand, an approach to his creations can be made through other images that reflect his work in other events. Thus, theintroduction of thelibrettobeginssaying "levanta la prima cortina, si rappresenta dalla seconda la Cittá di Parma, e si veggono la Gloria, Apollo, Saturno ed un Coro d'Hore" (La Filo, 1631, p. 1),otherexamples: "Scena prima che rappresenta la sala regia della Corte d'Onfale" (p. 11), "Scenaduodecima che rappresenta una stradavicinaalla Corte" (p. 27), "Scenadecimaquinta che rappresenta un Giardino" (p. 30), "Scenavigesimaprima che rappresenta la Città verso la Porta di Sardi” (p. 41), "Apertarsi la Torre, mostra un bagno, doveOnfale si trova pressoErcole" (p. 50), "La scena si fàMaritima” (p. 51), "Scena prima che rappresenta la stanzadella Maga” (p. 58), "Scenaterza che rappresentaloggedella Corte con duestatue" (p. 61), "Scenadecimasettima che rappresenta un bosco" (p. 85), "Scenadecimanona che rappresenta un luogo da Ballo" (p. 89). To whatisadded "Iardo, Lampa, Clorida e Danzatori con persone che giungono per veder la danza"), al final del segundo acto "Si cangia la scena in un bosco di Mirti, che rappresenta i campiElisi" (p. 100), "Quìsorgendovapori, e comparendo nubi, s'alzailbosco al Cielo" (p. 106), "La scenacangia in una Galeria" (p. 108), "Scenasettima che rappresenta una collinaintorno la Città" (p.120), "Sparita la sudetta mole si muta la scena in un'Armaria di Corte” (p. 230), "Comparisceun'Anfiteatro col serragliodellefereed una fonte” (p. 238), "Segue la sinfonia, e poi si muta in aria” (p. 252).

The machines to disguisethewaythefly of characterstook place becametheabsolutemaincharacters, showing a greatdebtwiththe master Francesco Guitti, as whenitissaid: "Apollo e Saturno si partorono e le Hore volando" (p. 4), "Amoresparisce a volo verso la città" (p. 6), "Si vede in aria Giove con Mercurio" (p. 7), "Scende Mercurio su'lfiume, da cui sorge un Coro di Ninfe" (p. 9), "Un gran terremoto fàcadertutte le mura" y "Da terrasorge una Torre, che imprigionaErcole" (p. 47), "Sorgedal Mar Netunno, e comparisce in aria il Sole" (p. 53), "Amorelevatodall' Aquila fino a mezz'aria le fugge" (p. 56), "Le statue si movonofacendoglicenno col capo" (p. 71), "Le statue si cangiano in dueDemoni e spariscono a volo" y "Si muta la scena in luogo di precipiziorridid" ondeesconomoltiMostri e Fantasmi" (p. 72), "Escedal pavimento un Mostro che lo possa in aria", "Fuggeferitoil Mostro, cadeFalconeedErcole lo sostiene, e spariscono i precipizi tornando le logge" (p. 74), "Qui si fà un ballo, e Fiorilla, et Erinda lo accompagnano col canto" (p. 96), "Lo gittaErcole in aria, con un calcio" (p. 224), "Con giriprecipitosicade un Mondo sù le spalled'Ercole" y "Torna la mole caduta pian piano, ad alzarsi” (p. 229), “Un Leone stà per uscire, a divorarRosmiro" (p. 241), "Argea da un mostro portava per aria et i studenti” (p. 250), "Apparisce una gran nuvola, dove si veggonoGiove, Giunone et Amore" (p. 253), "Si allarga la nube, dando ilvarco ad una lontananza, che rappresenta i recessi del Fato, dovesono le ImpresedelledueSerenissime Case" (p. 254), up to thelasteffect, bywhich "Si dilata la nube scoprendo la Gloria, doce si veggono i Dei" (p. 258), para rematar 
con la laudatoria final en la que el personaje del sol recitaba: "Viva pur Margarita, al lume divino, di sueluci altere, l'incarco destino, d'illuminar le sfere" (p. 258), and Marsconcluded: "Viva purRanuccio al Mondo, sarà Marte à lui secondo, ne a me siastrano, ceder l'armi a la sua mano" (p. 259).

Following these indications Pasetti's designs can be visualized in other pastimes or playful entertainments, like in the tournament Lestellecombattutedaglielementi, staged in Ferrara, in "città del ferro" to honour the papal legate SigismondoChigi about the marriage of two members of relevant families, Beatrice Bentivogli and the count ErcolePepoli in 1676 taking place in the famous Theatre of the Bold, remodelled on behalf of the Marquis PioEneadegl'Ibbizi by Pasetti himself, being given the name of the new sponsor ${ }^{31}$. In the description of the event, compared with the "spettacoliOlimpici, Pitii, Istmii e Nemei"32, the decorations are made available to the "Deitàchecondusero le Machine de Cavalieri": Mars, Flora, Iride, Vulcanoand Thetis.

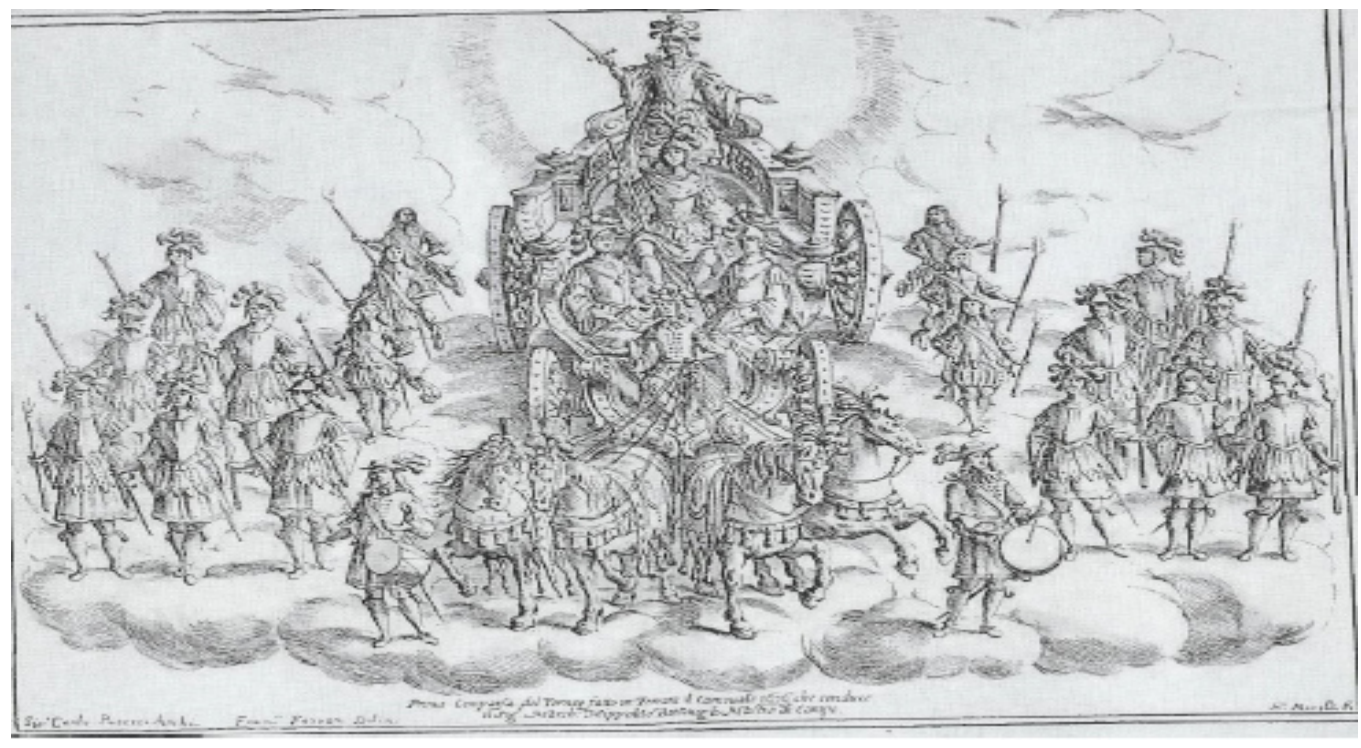

Fig9. Carlo Pasetti, Stelle Combatutte dagli Elementi, 1676. Carro de Marte.

It is said about showmanship in the same libretto of the Le StelleCombattute that when there is "amplificationiiperbolichedellapiù forte elloquenza, no solo non ingrandiscano, mà non arrivano à poteresprimere la ver forma di quello, la di cui vastirèeccedil'intelletto, che lo describe"33, and immediately it is recommended to attend the noble pastime to see "unaperfettissimaPittura, con Geometricaproportione, s' inferivaquantodovesseesserel'ampiezzadellaportentosa mole atterrata". But more spacifically, the text is full of Pasetti's skills or "mastery symmetry", who "nella forma presentefeceridurlo\& opera confacente al nomeméritamenteacquistatosinelleprofessionimattematiche, non-solo in Italia, mà per tutta Europa, di cui ne füArchitettura, e dalla cui intelligenza, parimentederivannotutte le machine del presentetorneo...per rappresentare al vivo unamaraviglia, e tantopiùquantochetuttiiPrincipi e personaggigrandid'Europa, ch'hannopostoilpiede in Ferrara, ocularmente ne hannoammirato la nobiltà, e la vaghezza".

Mars's chariot is described as a rich structure of noble work that simulates gold and silver with a shot of four horses that "came down from the clouds" "con motocosìplacido e regolato" (p. 28) driven by the field master of the tournament.

31. "Troppo era superioreall'insensatastruttura del Teatro, benche magnifica l'animata luce". Le StelleCombattutedagliElementi, torneo rapresentato in Ferrara da diversicavalieri, Ferrara, Per gliHeredi di Giulio BulzoniGiglio, 1676, Descrittione del Torneo, p. 5

32. Le Stelle Combattute dagli Elementi, Ferrara, 1676, Dedication of the Knights of the Tournament to the Very Eminent Prince of the Church, List of "interlocutori"

33. Le StelleCombattutedagliElementi, torneorapresentato in Ferrara da diversicavalieri, Ferrara, Per gliHeredi di Giulio BulzoniGiglio, 1676, Descrption of the Preliminaries of the Tournament 


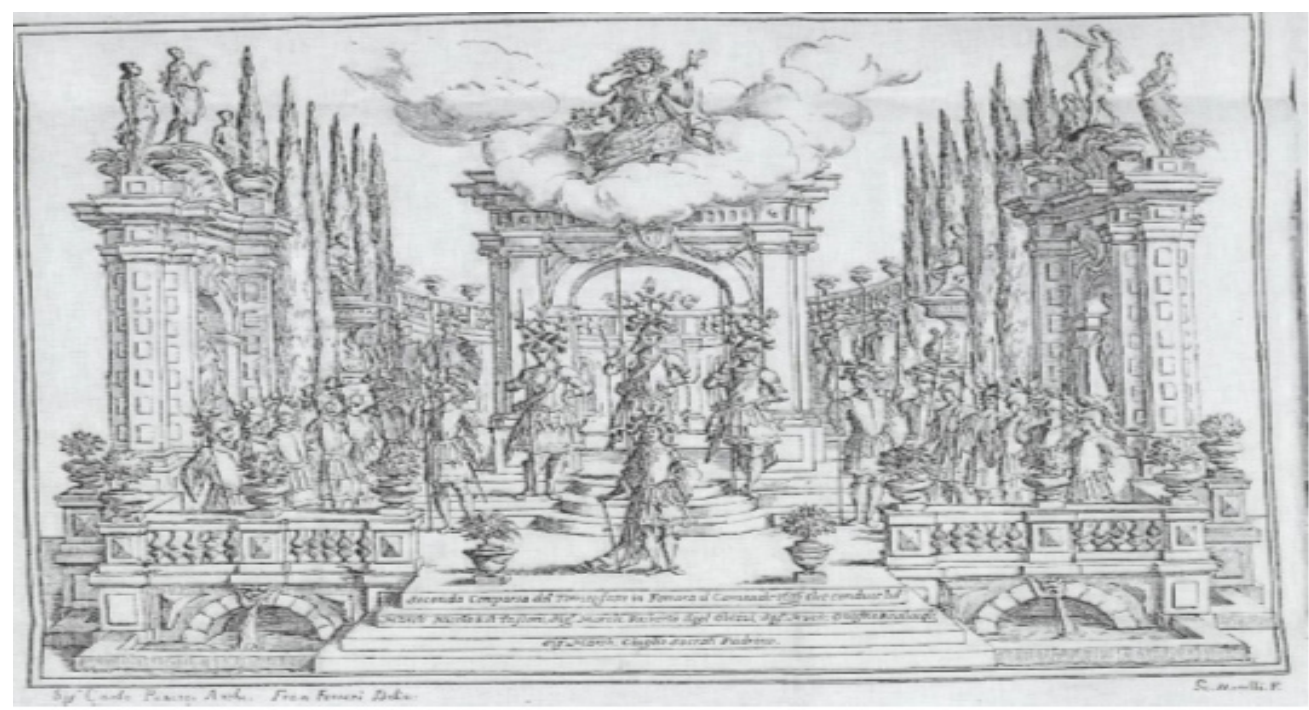

Fig10. Carlo Pasetti, Stelle Combatutte dagli Elementi, 1676. Caballeros de la Tierra

Only a bit further, within the same descriptive story, it is added about the decoration that a cloth was placed in front of the curious audience that showed the vision of a stately scene, where a garden appeared, an "ecenadipinta", that illustrated Flora's chariot, driven by the Knights of the Earth. In this scene a machine was used with which Jupiter appeared with Mercury "cheavanzandosi verso ilProscenio con musicaadattataallagravità del Personaggio, isuoisensiesprimeva" (p. 12). After it is pointed out that once the machine is put down on the scene ground, "in onta del propio peso naturale, e di quelloaccresciuto di gliventiquattropersone, chesostenevas'avanzò, come se nullahavesseportato, fino quasi all'Orchestra, ovefermatasi, sceferoiCavaglieri col loroaccompagnamento, et ilGiardino in più parte diviso, da ilatidellascenanascondendosi, sparidoppo, che Flora per incitareisuoiCampioniallaVittoria..." (p. 31). It is not the sole reference about the scenic set, because in the next page it says that "whilst the machine with which the Knights of the Earth were walking through the stage it mutated in Tragic with instruments playing in vagasinfonia, untila "Globo di Nuvole" appeared in the background, representing the Knights of the Air, and thus, of another of the elements codified by Thales of Mileto.

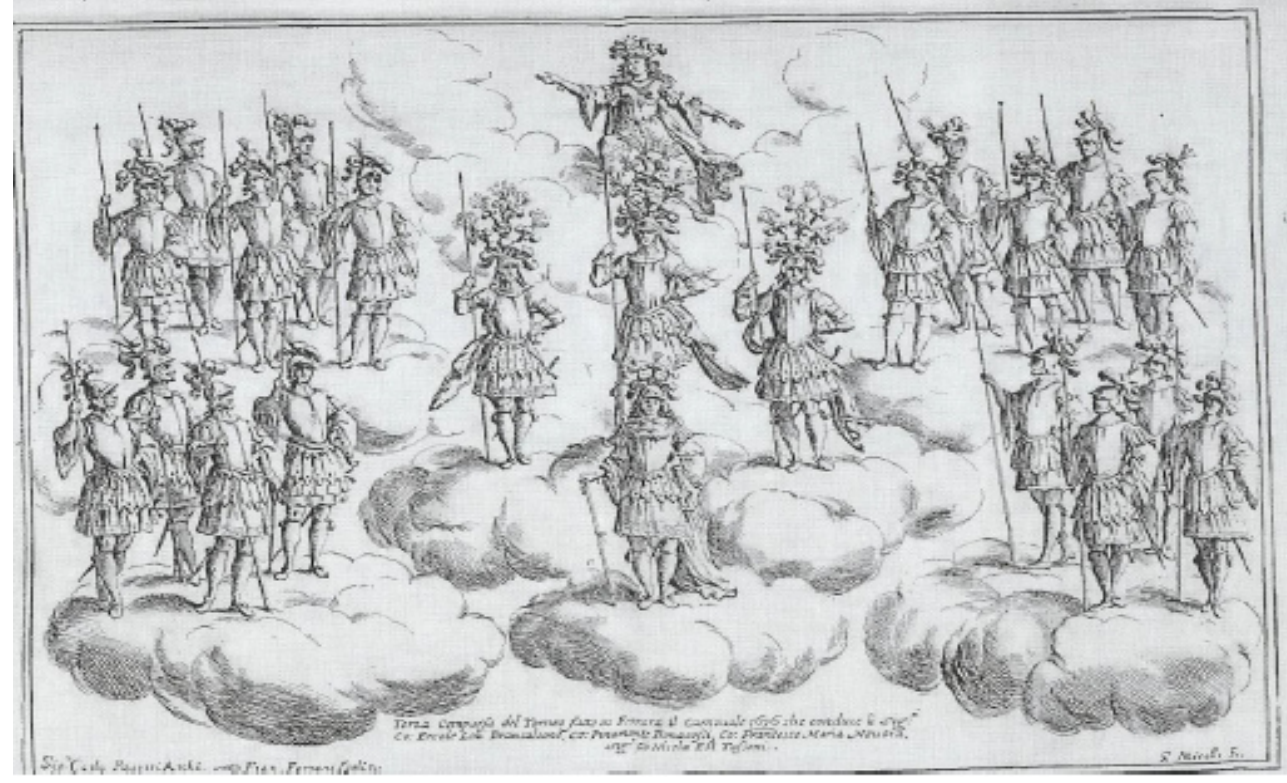

Fig11. Carlo Pasetti, Stelle Combatutte dagli Elementi, 1676. Los Caballeros de Aire conduciendo el Carro de Iris. 


\section{Glimpses of the scenography of Farnesian shows in Spain: Carlo Passetti's Filo}

According to the indications of the libretto, that apparatus should not represent other thing but the "Sunrise of those heroes that come from the East, neighbour of the bright sun---" (p.34) and after having moved widely far and wide the stage, after having gone down to the pavement of the proscenium, hided back within the fog, with Iris, who after having recited her verses went back to the skies.

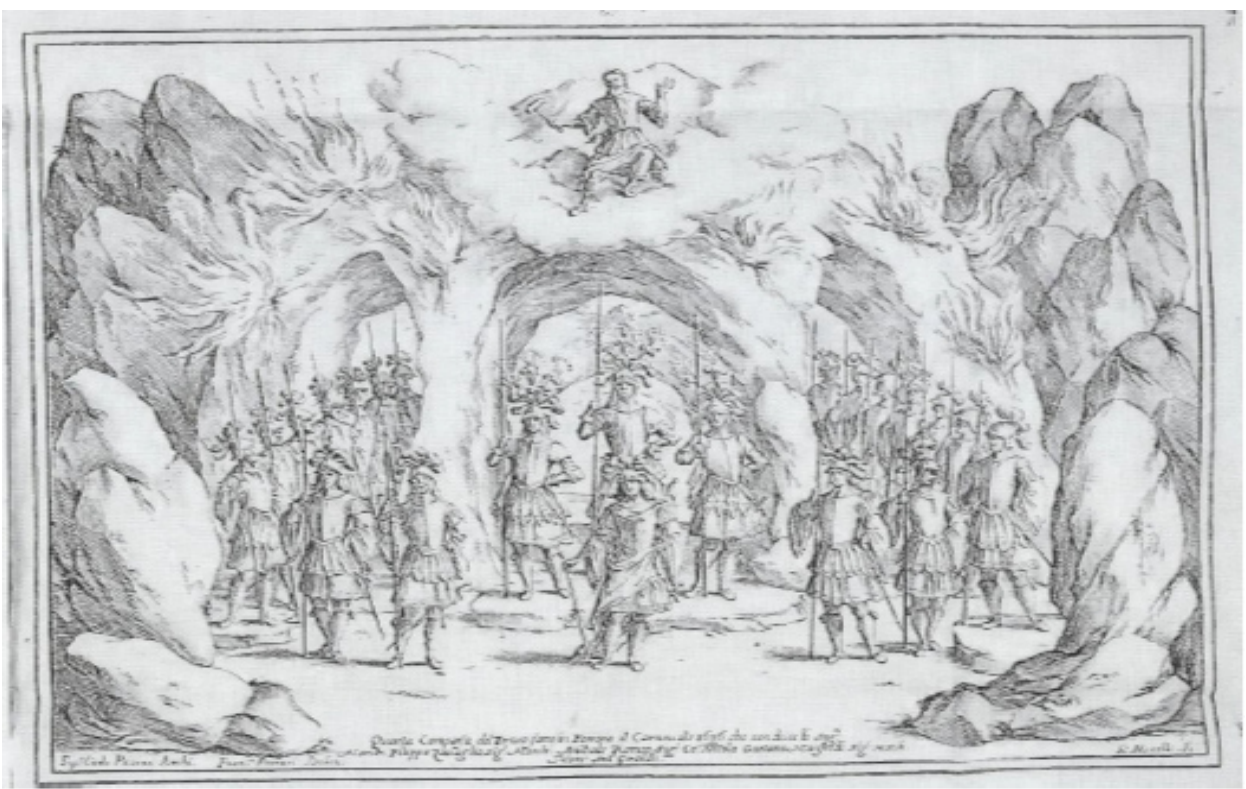

Fig12. Carlo Pasetti, Stelle Combatutte dagli Elementi, 1676. Gruta de Vulcano.

In what refers to the igneous element, it is referenced in the figure of Vulcan, as god of fire, who is invoked and represented upon a machine simulating a rock on the top of a hill, with a drilled "very beautiful Grotto", that brought forward the enthusiastic applause of the audience and that is considered the offspring of "arte, non meno di peritoArchitetto" (p.37), thanks to whom "the champions of fire" could be presented, seeking to arouse the audience: "Nell'avanzarsi la Machinacelebravai di lei portenti e animavaall'ardireisuoiCavaglieriilNume del fuoco..." (p. 37).

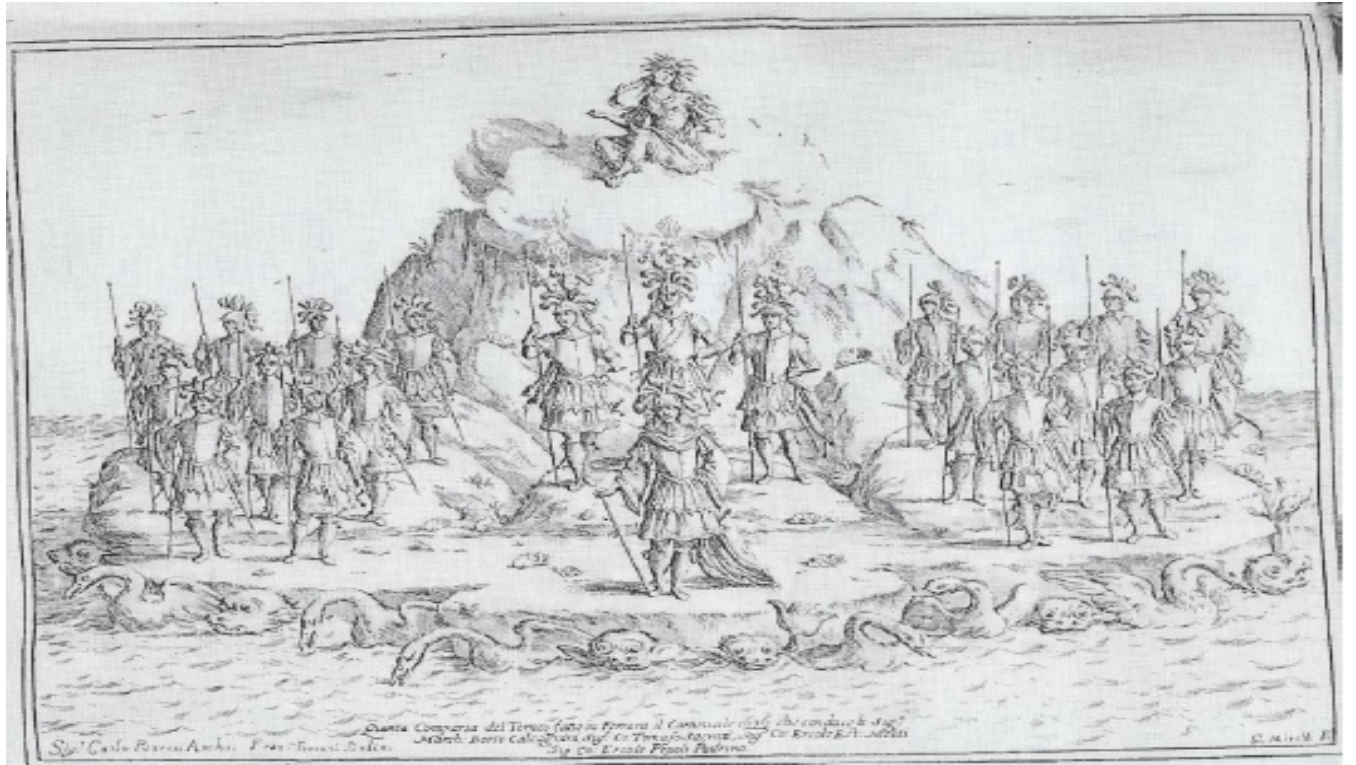

Fig13. Carlo Pasetti, Stelle Combatutte dagli Elementi, 1676. Caballeros del Agua. 
Glimpses of the scenography of Farnesian shows in Spain: Carlo Passetti's Filo

The aquatic medium is approached with the representation of the appropriate machine, escorted by a fantastic sea wildlife. It used to be one of the most spectacular moments of the different playful events, because it required both the speculative effort and the practical experience by the scenographer to simulate the water fiction. In this occasion, on what must have been the result of Pasetti's work, the text of Le stelle reads that there was a change in the set: "ildilettevole de Palazzicedevail loco all'oridezza de scogli. Il solido del Pavimento aprendosi in piùpartiricopertomiravasidal fluido dell'Acque...faceva vero naufragio l'artedelleScene dalle maraviglie di questa vista. Nelpiùlontanodella marina si vedeva un elevatoscoglio, tutto di Conchiglie\&altrifrutti di mare adorno. Era sostenuto di Sirene, Tritoni e Cigni, che gallegiante lo portavanosùl'onde. Possavanelpiùrilevato di esso la vaga Teti, che da i Campionidell'Acqua era la condottiera... Vestivanno di colore Celeste ... e portavasiquasisùl'orlo del Proscenio...." (p. 39).

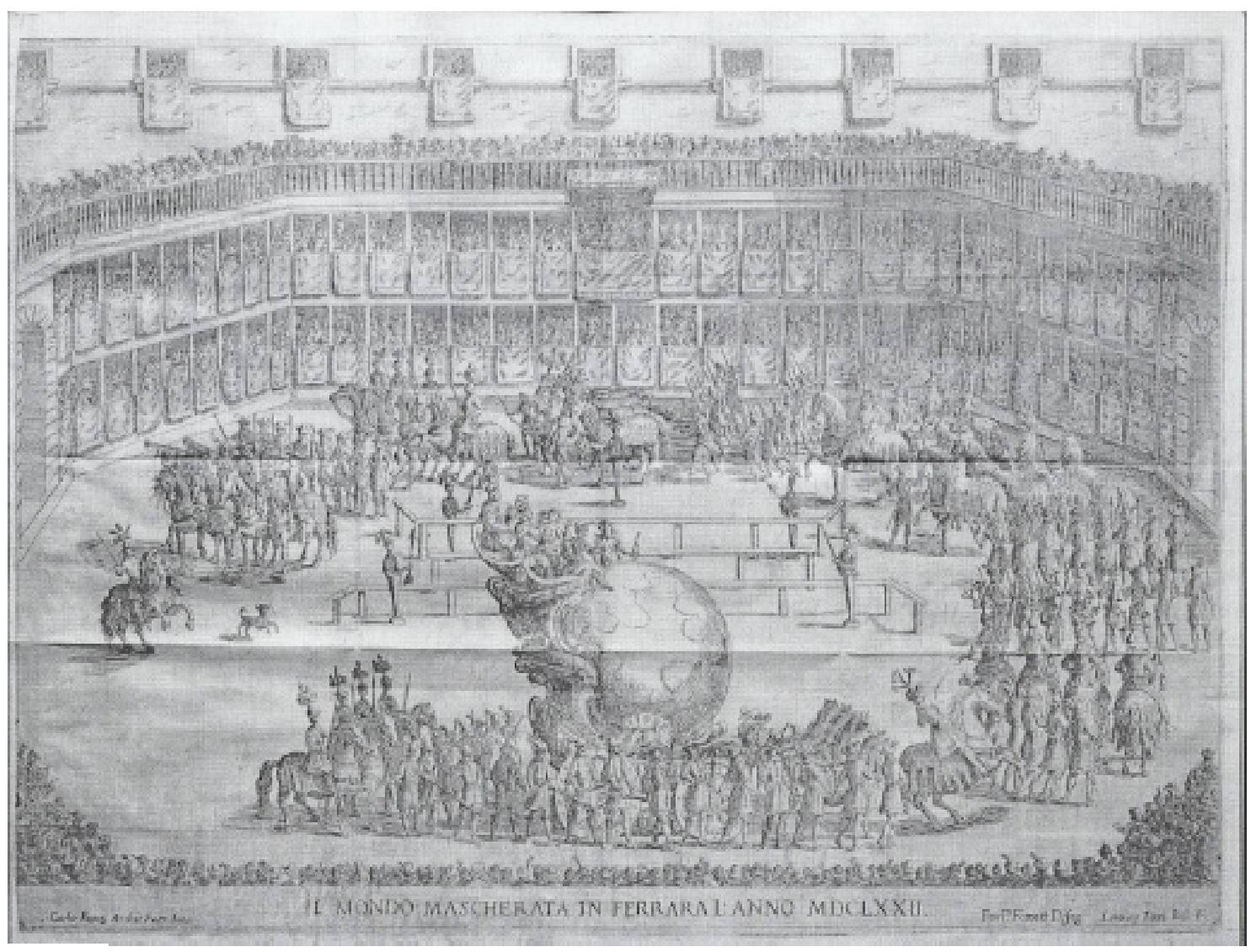

Fig14. Carlo pasetti, Il Mondo, Mascarada. 1672

The habit of using the city or parts of the palatine residence as an urban set dates back several centuries, at this point of the modern age. The cortile of the Pitti Palace or the Piazza di Santa Croce, in Florence, are just a couple of examples within a broad and generic context in which all the Italian rulers - and European by extension - are conscious about the propagandistic value of the different shows that have emerged from the Party. And within these, the tournament, with arthuric origins, is what better explains the symbolic meaning, the metaphor of chivalry and of the hero to whom the absolute kings want to resemble. The tournament ceases to be a war encounter to become a choreographed dance, with a main character or groups, thus generating the typology of what is known as italian "Carrusel" or "Caroselo"where submission and vassalage can be visualized. 


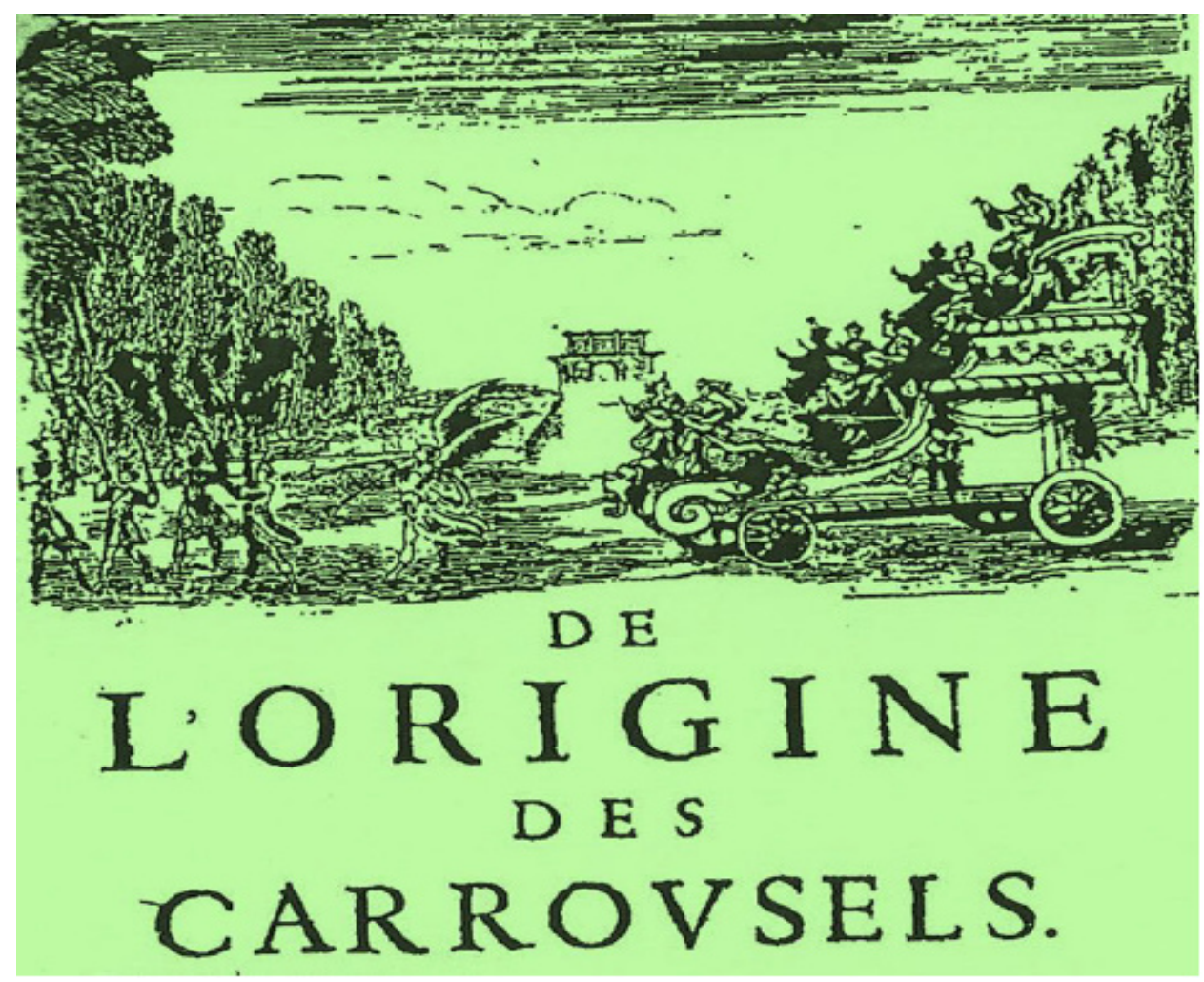

Fig15. C.F. Mènestrier, Traite des Tournois, Joustes, Carrousels et autres spectacles publics, 1669.

Pasetti took care of another tournament, even before assuming the decorations of Le stellecombattute, of whose libretto, like in La Filo, the author was Francesco Berni. Its name is Il Mondo, Mascarada ${ }^{34}$, with music composed by BastianoChierici, master of Capella of the lord of Ferrarain whom became the World main character ${ }^{35}$ (as a character itself) and the contenders, the four parts in which it divided, and by analogy it should be possible to infer that the master to whom the celebration was dedicated should reign. One of the first occasions in which there is memory that this issue of the four continents had been used in a courtly show was in the Ballet of the Widow Heiress of Billbahaut, that was staged in 1626 at the Louvre Palace, organized by the duke Henry of Nemours, quartermaster of the Pleasures of the Courtfrom 1621 to 1637, where the king of France, Louis XIII danced, some engravings of this event are preserved in the so-called Album Rabel, in the Cabinet of Engravings of the Louvre Museum. The dancers represented the different continents, from whose distant lands embassies were sent, paying tribute to the rich heiress and her lover Fanfan of Sotteville. On the other hand, there are many news either from the libretto or the general design of the event, apart that the author, Daniel Revel (1578-1637), gathered up some snapshots with a dominant burlesque style, proposed by the king's poet, Bordier, because the satire of the court itselfwas to be highlighted.

34. Il Mondo. Mascherata. Esercizio caballeresco da rappresentarse a caballo nelcortile di Ferrara, All'EminentissimoSignorCardinaleAcci aioliLegato et allesignore Dame, InventatoedammaestratodalsignorContePinamonteBonacossi, componimento del signorconte Francesco Berni, in Ferrara, per Giglio, 1672.

35. The metaphor of the world had also become main character in the gardened theatre of the Pitti Palace, Florence in the show named Il Mondo festejante , 1661, organized by Ferdinando Tacca (1619-1686) - son of the famous sculptor, who had been educated by the Parigisfrom whom it is known the huge episode of the Atlas, surrounded by a Carrusel that represented the continents, thanks to the picture engraved by Stefano della Bella, who also became the graphic chroniclerof all the parties in the region of Emilia-Romagna. A reference about Tacca can be (Merino, 2010) 


\section{Glimpses of the scenography of Farnesian shows in Spain: Carlo Passetti's Filo}

To describe the entry of the coach under the pallium in the case of the tournament celebrated in Ferrara, it can be read that: "dopoisudettivedrassientrarnelteatro un gran carroformato col Globodella Terra, e condotto da quattrocavalliguidati a mano, e con pelli di Leone vagamentebardatiscorreràegli con ingenioso e bell'artificio sotto quelglobo in tal forma, che a guisa di guscioabbracciandolo, nella parte dereraniavedràsollevarsi in alto a formare un nobilseggio. IvisedendofaràdemogorgonegiàcredutoNumedella Terra, e con lui faranno le quattroParti del Mondo. Appariràdietro, e da laticorteggiato da ventiquattroNazionidiverse, col seguito in fine d'altri orto personaggi a caballo in abito di Città e di Regni" ${ }^{36}$

And finally, referring to the scenographer the text reads "sichiamòil Signor Carlo Pasetti, il cui valorenell'Arc hitetturaesercitato da primiPotentatidell'Europa è giàpalese", to further continue with the description of the designed decorations:

"FormosinelCortile in un subito con ordine triplicato di palchi dalle partiquasi a figura ottagonail teatro..." (p. 9).

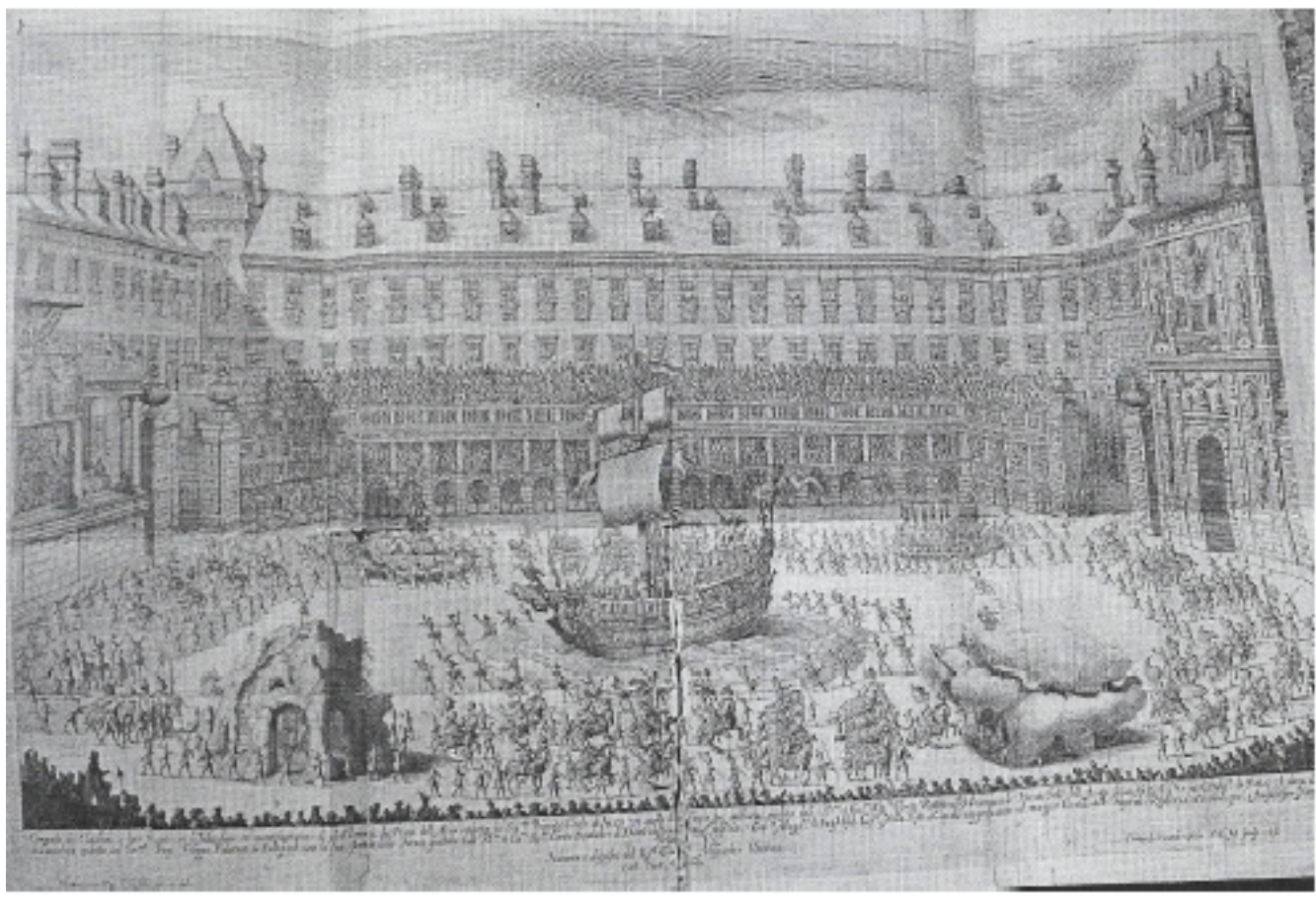

Fig16. Pasetti, Il Mondo, Mascarada,1672

Carlo Pasetti (1639-1695) was one of the scenographers selected to cre the machinery and decorations of the staging of La contessadell' Aria e dell'Aqua ${ }^{37}$, one of the huge parties celebrated in Vienna for the wedding of the emperor Leopold with the spanish princess María Teresa in 1666, with texts from Francesco Sbarra, imperial counsellor in Vienna, thanks to the experience accumulated during years in the design of decorations for courtly shows. Some of the illustrations were designed equally by Pasetti and Nikolausvan Hoy, engraved by Jan van Ossenbeck. The author of the music was Antonio Bertali and the choreography was Alessandro Carducci's, some of the arias for the horse ballet were composed by Johan Schmelzer, that appeared as chamber musician.

36. Il Mondo. Mascherata Ferrara, per Giglio, 1672: 15-16

37. Inserted on what has been named "a second summit of the wedding parties", after a preparation period of almost a year, that took place the 24th of January 1667 in the inner courtyard of the imperial palace, they concluded the following year with the staging of Il Pomo d'Oro (1668), the most well-known baroque opera, because the Theatre of the Curtain was not available before, the building that was specifically built for staging it. This issue is dealt in (Checa, 2003) 
Glimpses of the scenography of Farnesian shows in Spain: Carlo Passetti's Filo

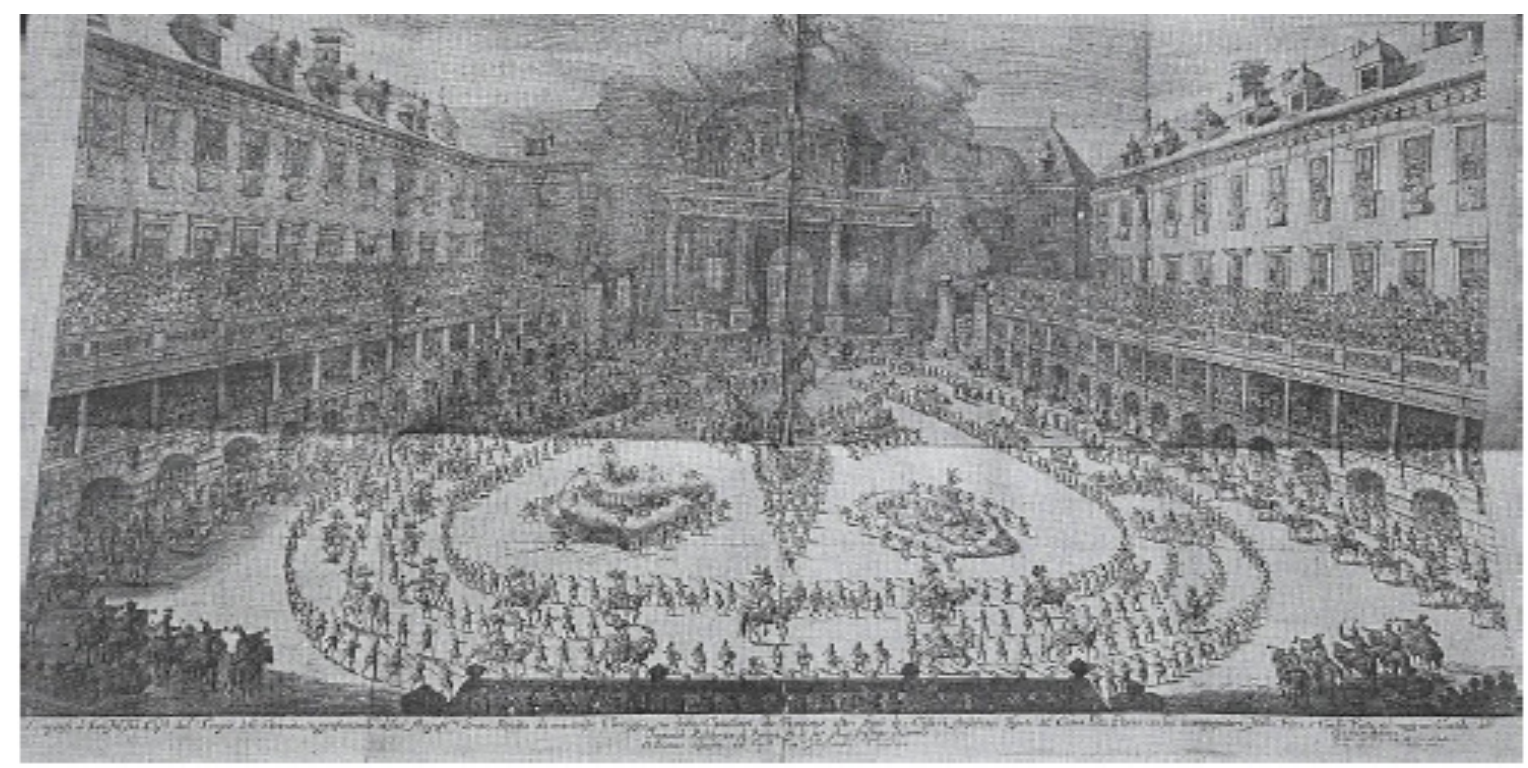

Fig17. Pasetti, Boda de Leopoldo I y Margarita Teresa. 1667. Entrada en el patio del Palacio Imperial. Biblioteca Marziana. It happened that the outdoor show was hampered by a furious winter storm that messed up the colorful wardrobe, as well as all prepared decorations and machinery, accordingly, the complex design of the choreography of the ballets, initially designed by Carducci, had to be simplified.

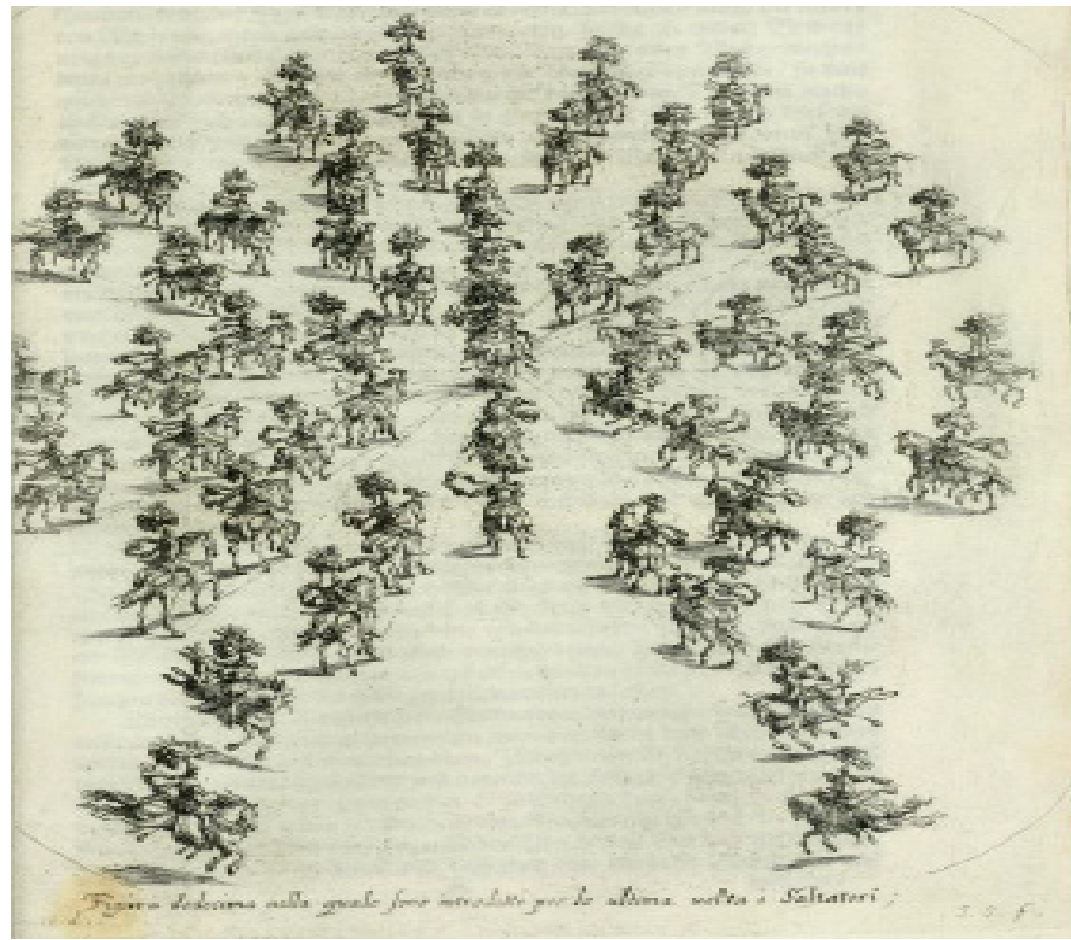

Fig18. Figuras del Ballet Ecuestre de las celebraciones con motivo del matrimonio de Leopoldo Iy la infant Margarita Teresa. Publications relating to the wedding of Leopold I, Holy Roman Emperor, and Margarita Teresa, Infanta of Spain], 1666. https://archive.org/details/publicationsrela00bert Sieg-Streit dess Lufft vnd Wassers : Freuden-Fest zu Pferd zu dem glorwürdigisten Beyläger beeder Kayserlichen Majestäten Leopoldi dess Ersten Römischen Kaysers ... vnd Margarita, gebohrner Königlichen Infantin auss Hispanien : dargestellet in dero kayserlichen Residentz Statt Wienn. Gedruckt zu Wienn in Oesterreich : Bey Mattheo Cosmerovio ... 


\section{Glimpses of the scenography of Farnesian shows in Spain: Carlo Passetti's Filo}

Pasetti, called upon specifically from Parma, was in charge of building thestands for the audience and a stunning decoration in the cortile of the palace ${ }^{38}$, that could transform itself in the Temple of the Eternity, apart from several chariots not less stunning, like one simulating the vessel of the Argonauts and the Chariot of Glory, collected in a libretto that includes Johann Heinrich Schmelzer's printed music score of the ballet and the description of the party.

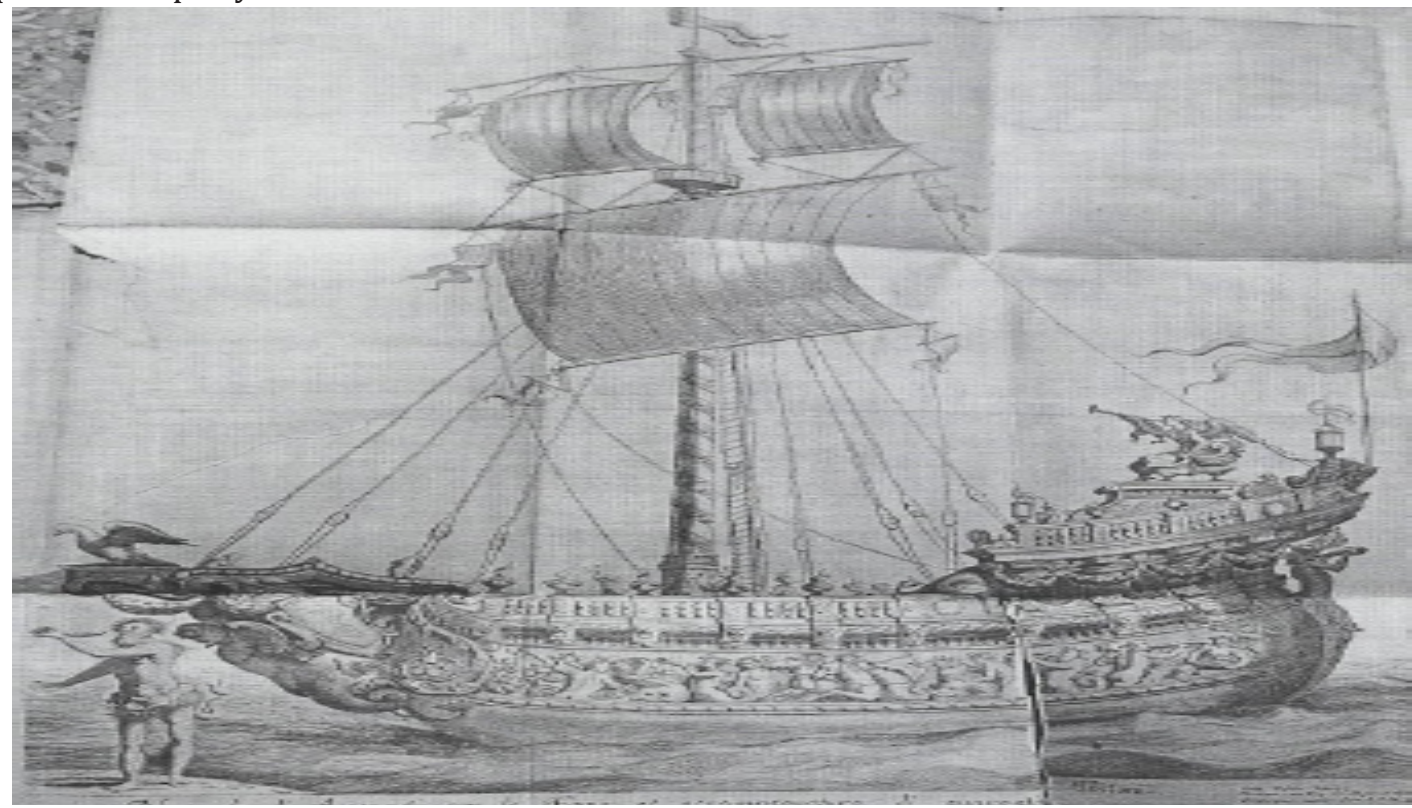

Fig19. Carlo Pasetti, Decoraciones para La Contessa dell aria e dell acqua, festa a caballo rappresentata nelle nozze dell'imperatore Leopoldo e dell'infanta Margherita delle Spagne, de Francesco Sbarra, impreso por Matteo Cosmerovio en 1667. Grabados conservados en la Biblioteca Marziana de Venecia.

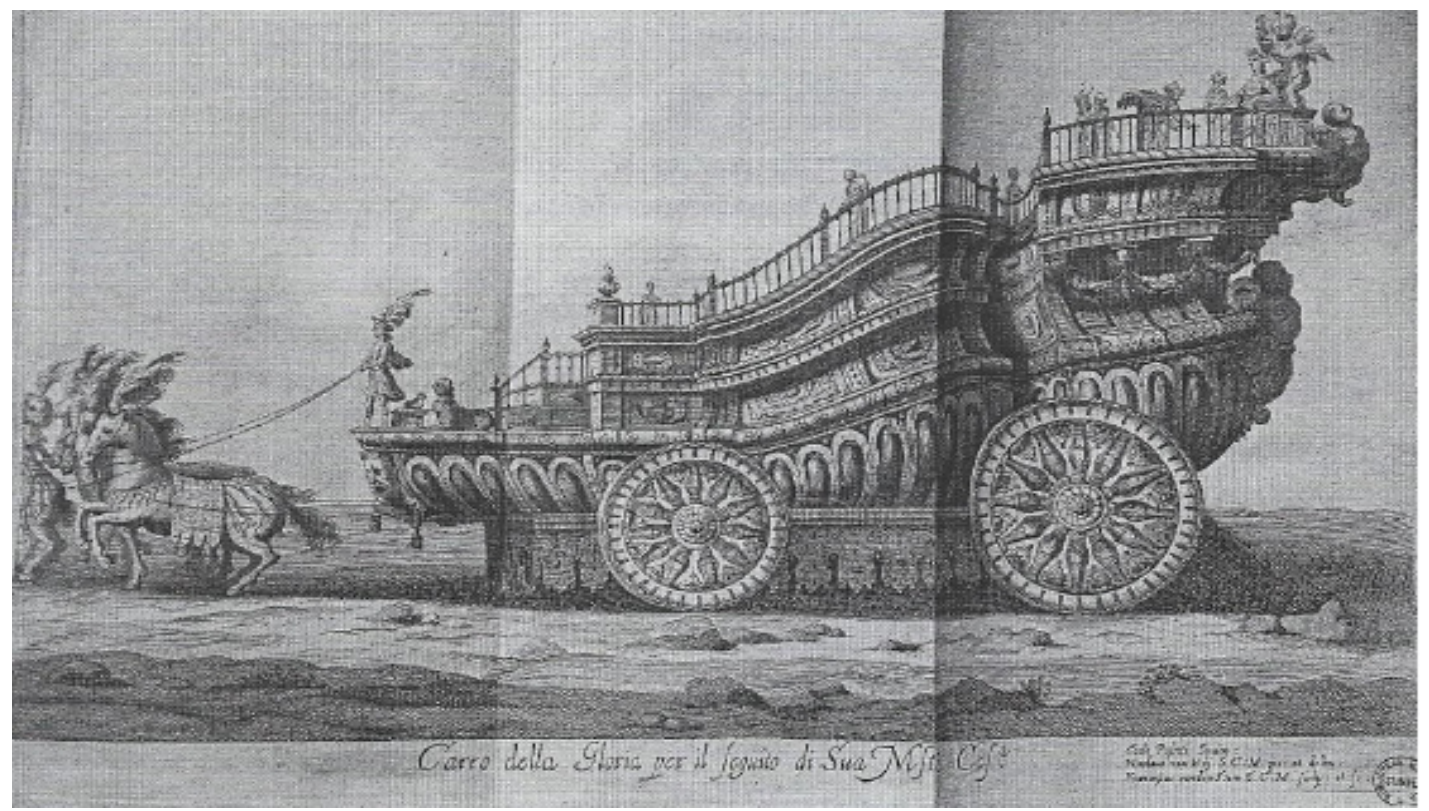

Fig20. Carlo Pasetti, Decoraciones para La Contessa dell aria e dell acqua, festa a caballo rappresentata nelle nozze dell'imperatore Leopoldo e dell'infanta Margherita delle Spagne, de Francesco Sbarra, impreso por Matteo Cosmerovio en 1667. Grabados conservados en la Biblioteca Marziana de Venecia.

38. That are analysed extensively in the magnificent catalogue of the exhibition Teatro y Fiesta del Siglo de Oro en tierraseuropeas de los Austrias (Royal Alcazar of Seville - Royal Castle of Warsaw, Poland, 2003) curated by (Díez Borque, 2003) 


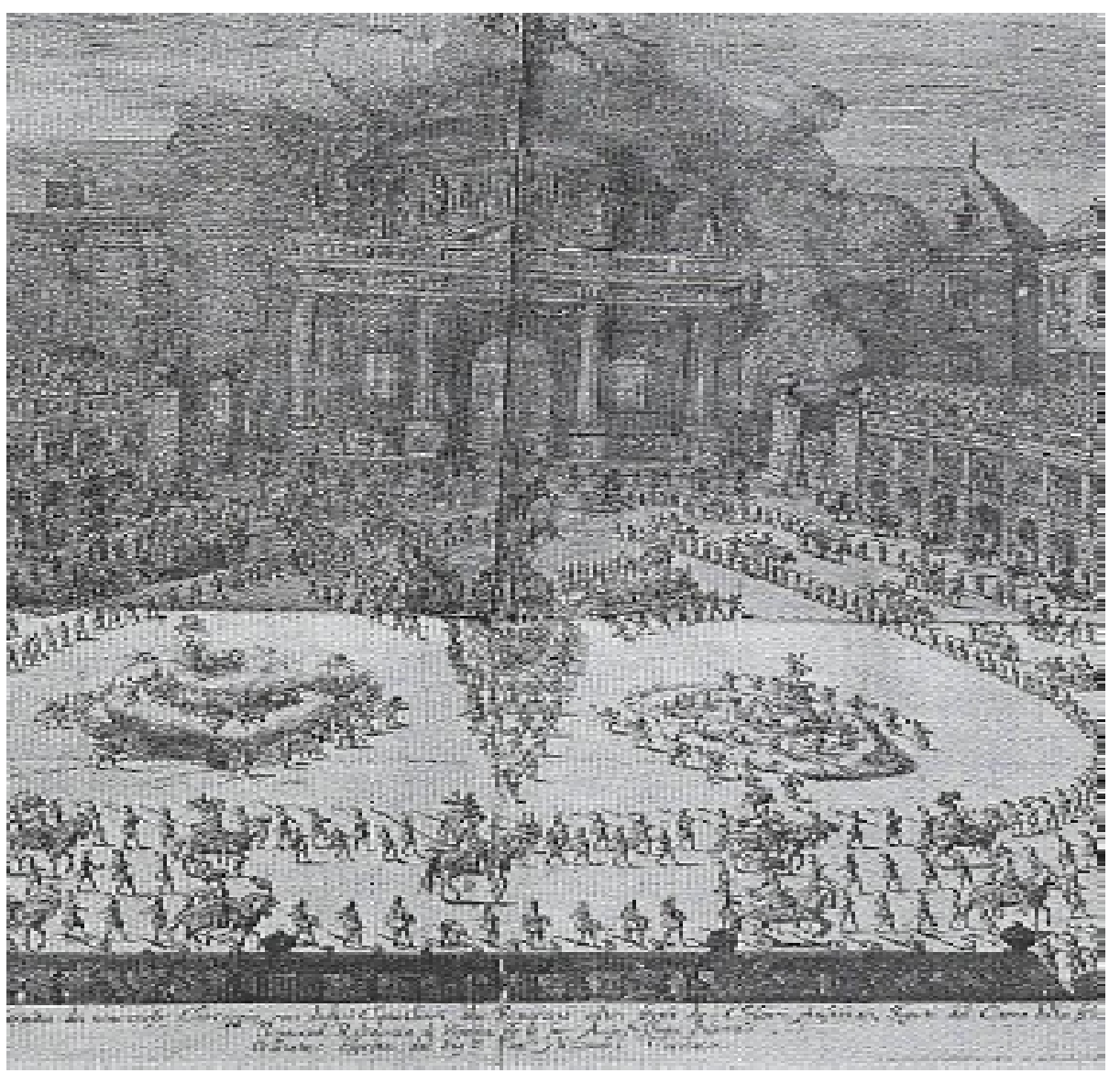

Fig21. Carlo Pasetti, Decoraciones para La Contessa dell aria e dell acqua, festa a caballo rappresentata nelle nozze dell'imperatore Leopoldo e dell'infanta Margherita delle Spagne, de Francesco Sbarra, impreso por Matteo Cosmerovio en 1667. Grabados conservados en la Biblioteca Marziana de Venecia. Detalle.

The biggest moment came with the triumphal entry of emperor Leopoldo on top of the four elements; this fact symbolically meant that he was the legitimate sovereign of the globe, to whom his subjects had to submit voluntarily due to his powers to dominate both the terrestrial and the celestial cosmos, as a colossal paradigm of good government, being thus liable to receive homage and fealty without having had to attend a battlefield different from a court, crowned by Glory, that awarded him the maximum prize, that is, the Golden Fleece, of the Habsburgs, since the creation of the Order by Philip of Burgundy. And, obviously, such an emblematic program and metaphor could not be "read" in isolated terms, but as part of the political geostrategy, that allows to understand the chessboard where each of thecharactersat the time represented a specific role, everybody applying for the same legacy, the spanish throne, though currently diminished in its unlimited boundaries, still very attractive for its european competitors. It was, in fact, a big scale thematic tournament where the contenders used even more the available propaganda resources, of the playful court, than the arm resources in the military battlefields; A war that was won before in the courtesan stage thanks to the scenographic resources, where the italians had the advantage of the long experience. Based in this practice, Pasetti ${ }^{39}$ was part of a large team of versatile skilled artists that could manage within the springs of the party to convey a message, at this point 39. It is difficult to find information about Pasetti, apart from the isolated references, mostly engravings catalogue index cards, where his work can be traced, especially in the wider framework included within the team works with the Burnacini in Austria. And, even though a study might exist about the plays for which he designed the decoration and the scenic machinery, it is mostly about literary analysis. Regarding this fact the proposed approach is ajoint one in what refers to La Filo, but using also his most significant works, especially of those of which illustrations are available, in order to calibrate its function as scenographer. In doing so it has been unavoidable to consult and study the show in the parmesan court by (Mamczarz, 1988) 


\section{Glimpses of the scenography of Farnesian shows in Spain: Carlo Passetti's Filo}

absolutely needed as a political instrument and doctrinal and didactic resource. Some have called it "unhidden exhibition" with remarkable success, thanks to the invention of architectonic "marvels" and ephemeral structure machinery, through which the speculative doctrinarian message, designed by the scholars of the Academies and intellectual sources of the absolute monarchies, was channelized.

\section{CoNCLUSIONS}

Several conclusions can be drawn from what has been presented. Firstly, a gradual transition takes place during several centuries, from a literature to which a decoration is rustled up by the hands of the multifaceted artists of the humanistic renaissance ${ }^{40}$, to the coding of a specific genre, the Libretto ${ }^{41}$ that worked as a compilation of the story, simultaneously it was a historical account, with the graphical testimonies of the different episodes within the Party (that as an specific genre it is understood that it must be written with a capital letter)or, strictly speaking, of the purely theatrical scenographic decorations, of the music scores, as well as emblematic, allegorical and symbolic interpretations.

From the point of view of the scenographic analysis, Pasetti's works become the consolidation of a prototypical formula, tested during all the century, since the model of the decorations linked with the four elements began to settle, representing the same stability as the classes society, the equilibrium that applied both in the cosmological and earthly universe, in charge of the ruler with the best competence to hold power and demand people's submission. Considering this composition of the cosmos, it is unavoidable to mention the social mindset in relation with the "music of the spheres" as a substantial part of harmony, understood as equilibrium or social or spiritual order. The correspondence of the nine celestial spheres with the nine Muses is due to the proposal of the neopythagoreanMartianusCapella (V century B.C.) and its subsequent correlation with the color scale and musical tones, where Apollo masters both the general artistic creation and the musical creation especially, including the chord of sounds ${ }^{42}$. The "four elements"were those necessary for the creation of the world following the philosophy of Thales of Mileto, that exemplified the celestial order and the good rule of the Prince.

This elaborate staging, using an iconography created within the frame of the playful, openly seeked submission, the substantial element on which the rhetoric of power of the king is based during the modern age. A scenography inspired in Athanasius Kircher's thought of the principlesin his Ars magna lucis et umbrae ${ }^{43}$, Rome 1665, where the sun represents the Tragedy, as Apollo, god of the Sun and the Muses, conqueror of the Telluric forces that inhabit the insides of the Earth, in a similar way as the earthly matters has its own location, for example in the typology codified by Vitruvio for one of the three dramatic genres, the comedy. Thus, it could be understood the need to include usually certain prototypical decorations in the sets of the different types of shows on which the

40. LikeLa Talanta (1588) by Pietro Aretino, la Pellegrina (1589) byGirolamoBargagliortheCofanaria(1593) by Francesco d'Ambra

41. The Libretto (as an independent genre it is understood that it should be written with an initial capital letter) or "drama per musica" or also "opera in musica" gradually strengthened during the XVII century as an "eclectic" genre, as it has been known. They were texts written by court poets or members of the different academies, that channelled through those works the secular ideology of the rulers. A productive activity where several authors specialised, mainly during the second half of the century. It is an interesting document that used to include at the beginning information about the date and place of the show, the name of the composer or composers of the music, the designers of the decoration and of the scenic machinery together with the synthetic engravings of the scenographic staging, of the characters and introductory chapters where the allegoric and metaphoric meanings that had to be inferred from the story were stated. This "passion" or fascination for this literary typology explains the wonderful collection of document collections such as those of the Estense,Braidense or Marcian Libraries in Italy, that are many less in Spain, and more scattered between the collections of National Library of Spain (BNE), (mostly coming from the collection of the Royal Palace) and libraries of the national Heritage, such as the one in El Escorial, where the copy of La Filo mentioned above, can be found. See (Bracca, 2014), (Sartori, 1990-1994), (Rosand, 1980), (Smith, 1981), (Accorsi, 1989), (Bianconi, 1995), (Bianconi, 1987). In the Hispanic environment several good works can be consulted, such as (Soriano García, 2016), see also (García, 2007) and (Bravo Ramón, 2015)

42. "In the sanctuaries of the Muses, like the one in Helicon reproduction is worshiped, but they also represent the adequacy to royalty, as promoters and singers of Zeus and as patrons of the poets. These are to kings like the Muses to Zeus. The poets exist due to the muses like Zeus to the kings (Plácido Suárez, 2008)

43. AthanasiiKircheri, FuldensisBuchonii ... Ars magna lucis et vmbrae in decemlibrosdigesta :quibusadmirandaelucis et vmbrae in mundo, atqueadeovniuersanatura, vires effectusq. vtinoua, itavarianouorum ...Romae : sumptibusHernanniScheus, ex typographiaLudouiciGrignani, 1645 (1646), BibliotecaHistórica UCM- FondoAntiguo, BH FLL 21191

American Research Journal of History and Culture

Page 23 
Glimpses of the scenography of Farnesian shows in Spain: Carlo Passetti's Filo

Party had diversified. A genre created as a complex semiotic entity, global and integrative, and multipurpose, with varied semantics and multiple readings, that invites the optical illusion, where the scenographer or "senses engineer" becomes the main inductor of a behavior pointing to submission, on which the baroque image policy is based.

A last note referring to the origin of the works that have to do with the XVII century's scenography, scripts and engravings that can be found in Madrid: A great part of it, or even most of it that is deposited in the National Library (BNE) comes from the Royal Library ${ }^{44}$ and the rest from the Library of the Imperial College. Some of these have ended in the Historic Library "Marqués de Valdecilla" and exceptionally in the Library of the Monastery of El Escorial, this situation turns the la Filo into an interesting document that allows to deal with the figure of Pasetti, not just with his biography, of which no more working news are available, but as heir of the Aleotti's parmesan scenography, because moreover he is one of the italianscenographers of the Burnacini's (Giovanni and Ludovico) "task force", who maximized the degree of richness within the ceremonial and iconographic protocols of the Party, and diffused them through Austria and central europe. On the other hand, it is an exponent of the turning point of influence and reference in the show. While during the first half of the century this material allows to trace the close relationship between the spanishand the florentine courts, libretti such as this one show a bigger concern for what was being done in the north of italy, on the other part of the Habsburg's empire and in the kingdom of France.

\section{REFERENCES}

AAVV, 1998. El Teatro Italiano. En: J. E. Carbonell, ed. Actas del VII Congreso Nacional de Italianistas. Valencia: Universidad de Valencia.

Accorsi, M., 1989. Problemi testuali de libretti d'opera fra Sei e Settecento. Giornale storico della Letteratura italiana, CLXVI(534), pp. 212-235.

Balestrieri, L., 1909. Feste e spettacolo alla corte dei Farnesi. Parma: Donati.

Bianconi, L., 1995. Hors d'ouvre alla filologia dei libretti. Il Saggiatore Musicale, Volumen II, pp. 143-154.

Bianconi, L. a. P. G., 1987. I libretista. En: Storia dell'opera italiana Vol. IV. Torino: EDT/Musica, pp. 233-291.

Bracca, S., 2014. Il libretto d'opera, l'avant-première del drama musicale. En: L'occhio e l'orecchio. Immagini per il dramma per música nella Venezia del '600. Treviso: Zel Edizioni, pp. 30-54.

Bravo Ramón, F., 2015. Obras teatrales de carácter operístico del reinado de Felipe IV. Pontevedra: Academia del Hispanismo.

Carandini, S., 1995. Teatro e spettacolo nel Seicento. Bari: Biblioteca Universale Laterza.

Checa, F. (. P., 2003. Cortes del Barroco. De Bernini y Velázquez a Luca Giordano (Cat. exp.15/10/2003 TO 11/01/2004)). s.l.:SEACEX.

Ciancarelle, R., 1987. Il progetto di una festa barocca: alle origini del Teatro Farnese di Parma (1618-1629),. Roma : Bulzoni.

Cirillo, G. a. G. G., 1989. Il Trionfo del Barocco a Parma nelle feste farnesiane del 1690. Parma: Banca Emiliana.

De Santis, M., 2012. Committenza, mediazione, poesis, musica e spettacolo nella Firenze di primo Seicento. Intorno a due recenti studi su Michelangelo Buonarroti il Giovane. Ricercare. Rivista per lo studio e la pratica della musica antica, XXIV(1-2), pp. 191-202.

44. (Merino, 2014) 
Glimpses of the scenography of Farnesian shows in Spain: Carlo Passetti's Filo

Díez Borque, j. M. (., 2003. Teatro y Fiesta del Siglo de Oro en tierras europeas de los Austrias. Royal Alcazar of Seville - Royal Castle of Warsaw: Ediciones el Viso.

Fiocca, A., 1998. Gian Battista Aleotti e gli ingegneri del Rinascimento. Florence: Olschki.

Gallo, A., 1973. La prima representazione al Teatro Olimpico, con il progetti e le relazioni dei contemporani. Milan: Ediciones Il Polifilo.

García, B. a. L. M. L., 2007. Dramaturgia festiva y cultura nobiliaria en el Siglo de Oro. Madrid: Iberoamericana Vervuert.

Jarrard, A., 2003. Architecture as performance in seventeenth century Europe. Court ritual in Modena, Rome and Paris. Cambridge: Cambrige University Press.

Lavin, I., 1964. On the unity of the arts and the Early Baroque Opera House in the "Lettres de Parme (1618, 1627-28), et debuts du Theâtre Baroque”. En: J. Jacquot, ed. Le lieu Théâtral à la Renaissance. Paris: s.n., pp. 105-158.

Leclerc, H., 1942. Les origines italiennes de l'architecture théâtrale moderne. Paris: Droz.

Magagnato, L., 1954. Teatri italiani del Cinquecento. Venice: Neri Pozza.

Mamczarz, I., 1988. Le Theatre Farnese de Parme et le drame musical italien (1618-1732). Florence: Leo S. Olschki Editore.

Mattei, F., 2010. Giambattista Aleotti (1546-1636) e la Regola di Jacopo Barozzi da Vignola della Biblioteca Ariostea di Ferrara (ms. CI. I, 217). Annali di architettura. Rivista del Centro internazionale di studi di architettura Andrea Palladio, Issue 22, pp. 101-124.

Mazzoni, S., 1998. L'Olimpico di Vicenza: un teatro e la sua "perpetua memoria”. Florence: Le lettere.

Mazzoni, S., 2013. Edipo tiranno all'Olimpico de Vicenza. En: Dionysus et machina IV. s.l.:s.n., pp. 280-301.

Mazzoni, S., 2013. Oltre le pietre: Vespasiano Gonzaga, Vincenzo Scamozzi y el teatro de Sabbioneta. En: Teatro clásico italiano y español. Sabbioneta y los lugares del teatro. Valencia: Publicaciones Universitat de Valencia, pp. 11-63.

Merino, E., 2008. Los diseños escenográficos de Burnacini para Il Pomo d'Oro de Cesti y Sbarra, en la Biblioteca Nacional de Madrid. Anales de Historia del Arte, Issue 18, pp. 141-166.

Merino, E., 2010. La huella de los escenógrafos italianos en España: Ferdinando Tacca (1619-1686). [En línea] Available at: https://biblioteca.ucm.es/pecia/43279.php [Último acceso: 08 enero 2018].

Merino, E., 2014. Del escenario cortesano a la BNE: Un viaje historiográfico sobre historia del espectáculo y artes escénicas.. Boletín de la Federación Española de Asociaciones de Archiveros, Bibliotecarios, Arqueólogos, Museólogos y Documentalistas (ANABAD), 1(64), pp. 113-124.

Ojeda, M. d. V. y. P. M., 2013. Teatro clásico italiano y español. Sabbioneta y los lugares del teatro. Valencia: Publicaciones de la Universitat de València .

Pieri, M., 1989. La nascita del teatro moderno in Italia tra XV e XVI secolo. Turin: Bollati Bolinghieri.

Pietropaolo, D. a. P. M., 2011. The baroque libretto. Italian Operas and Oratorios in the Thomas Fisher Library at the University of Toronto. Toronto: University of Toronto Press.

Pirrotta, N., 1984. The Orchestra and the Stage in Renaissance Intermedi and Early Opera. En: Music and Culture in Italy from the Middle Ages to the Baroque. Cambridge MA: s.n., pp. 210-216.

Plácido Suárez, D., 2008. Poder y discurso en la antigüedad clásica. Madrid: Abada editores.

American Research Journal of History and Culture

Page 25 
Glimpses of the scenography of Farnesian shows in Spain: Carlo Passetti's Filo

Poleross, F., 2003. Ente majestas y modestas: Sobre la representación del emperador LeopoldoI. En: Cortes del Barroco. De Bernini y Velázquez a Luca Giordano (Cat exp. 15/10/2003, 11/01/2014). Madrid: SEACEX, pp. 151-160.

Puppi, L., 1963. Il Teatro Olimpico. Vicenza: Neri Pozza.

Rosand, E., 1980. In defense of the venetian libretto. Studi musicali, Issue 9, pp. 271-285.

Sartori, C., 1990-1994. I libretti italiani a stampa dalle origini al 1800: catalogo analitico con 16 indice. Cuneo: Bertola \& Locatelli.

Schrade, L., 1960. La representation d'Edipo tiranno au Teatro Olimpico: Vicence 1585. Ètude suivie d'une edition critique de la tragédie de Sophocle par Orsatto Giustiniani et de la musique des choeurs para Andrea Grabrieli. Paris: Centre National de la Recherche Scientifique.

Smith, P., 1981. La decima musa. Storia del libretto d'opera. Florence: s.n.

Soriano García, M. V., 2016. Del texto dramático-lírico a la representación: la obra dramática fuente de la ópera, el libreto y la puesta en escena. Un breve ejemplo en Don Giovanni. Boletín de la Real Academia de las Letras y las Artes de Extremadura, Volumen 24, pp. 479-526.

Warburg, A., 1859. The theatrical costumes for the Intermedi of 1589. Bernardo Buontalenti's designs and the Ledger of Emilio de Cavalieril. [En línea] Available at: http:77tems.umn.edu/pdf/Warburg-Theatrical.pdf [Último acceso: 07 january 2018].

Zorzi, L., 1977. Il teatro e la città. Saggi sulla scena italiana. Turín: Giulio Einaudi editore.

Citation: Esther Merino. "Glimpses of the scenography of Farnesian shows in Spain: Carlo Passetti's Filo". American Research Journal of History and Culture ; V4, I1; pp: 1-26

Copyright (C) 2018 Esther Merino. This is an open access article distributed under the Creative Commons Attribution License, which permits unrestricted use, distribution, and reproduction in any medium, provided the original work is properly cited.

American Research Journal of History and Culture

Page 26 